\title{
ODNOS JEZIKOVNIH UPORABNIKOV DO SPLOŠNIH ENOJEZIČNIH SLOVARJEV: SLOVENSKI VIDIK
}

\section{Špela ARHAR HOLDT}

Center za jezikovne vire in tehnologije Univerze v Ljubljani (Filozofska fakulteta, Fakulteta za računalništvo in informatiko)

Arhar Holdt, Špela. (2018): Odnos jezikovnih uporabnikov do splošnih enojezičnih slovarjev: slovenski vidik. Slovenščina 2.o, 6 (1): 1-36.

DOI: http://dx.doi.org/10.4312/slo2.0.2018.1.1-36.

Prispevek predstavlja rezultate slovenskega dela mednarodne raziskave o odnosu jezikovnih uporabnikov do splošnih enojezičnih slovarjev. Raziskava je potekala leta 2017 v okviru dejavnosti Evropske mreže za e-leksikografijo (ENeL). V Sloveniji je vprašalnik izpolnilo 619 posameznic in posameznikov, med katerimi so tako redni slovarski uporabniki kot tisti, ki slovarje uporabljajo redkeje. Rezultati kažejo, da vprašani do slovarskih podatkov najpogosteje in najraje dostopajo s pomočjo računalnika. Slovar se pogosto uporablja za preverbo ustreznosti jezikovnih izbir (lastnih in tujih), vendar njegova referenčnost ni razumljena kot absolutna, saj se ob informacijskih vrzelih uporabniki privzeto obračajo na številne druge vire. Slovar se tipično dojema kot izčrpen vir informacij o slovenščini, namenjen širši javnosti. Simbolna vloga slovarja (avtoriteta, nacionalni simbol) se v uporabniških odgovorih zrcali redkeje, implicitno pa jo nakazuje nenaklonjenost uporabnikov, da bi knjižni slovar oddali ali zavrgli, četudi uporabljajo le digitalno različico. Med vprašanimi vlada močna podpora javnemu financiranju priprave splošnih enojezičnih slovarjev, temu ustrezno pa se brezplačnost slovarja pojavlja že na drugem mestu prioritetnih značilnosti, takoj za zanesljivostjo vsebine. Med prioritetami se pojavita še enostavnost uporabe slovarja ter sodobnost vsebine. Izsledke raziskave je mogoče uporabiti pri razvoju slovarskih virov in za oblikovanje nadaljnjih korakov slovenskih slovaropisnih uporabniških raziskav.

Ključne besede: uporabniške raziskave, slovarska raba, odnos do slovarja, splošni enojezični slovarji 


\section{OKVIR IN NAMEN RAZISKAVE TER UVODNA OPOZORILA}

Leta 2017 je bila v sklopu dejavnosti Evropske mreže za e-leksikografijo (ENeL) ${ }^{1}$ opravljena mednarodna raziskava o odnosu jezikovnih uporabnikov do splošnih enojezičnih slovarjev (Kosem 2017). Raziskava je vključevala 29 držav, pri izvedbi pa je sodelovalo 58 raziskovalcev iz celotne Evrope. Raziskava ugotavlja, v katerih situacijah se splošni enojezični slovarji uporabljajo, kakšen je uporabniški odnos do tovrstnih priročnikov, načinov njihovega financiranja in katere značilnosti slovarjev so v sodobnem času uporabnikom prioritetne. Vrednost raziskave, ki je $\mathrm{v}$ izvedbenem smislu najobsežnejša evropska slovaropisna uporabniška študija do zdaj, je v prvi vrsti primerjalne narave. Ob analizah, ki bodo slovenske rezultate postavile v širši evropski kontekst, pa je smiselno ločeno zagotoviti natančnejši vpogled v slovenski del rezultatov.

Ker v iskanju ustrezne mednarodne splošnosti vprašalnik občasno zgreši točke zanimanja na posameznih nacionalnih ravneh, je bilo mednarodno enotnemu delu ankete na nacionalni ravni mogoče pripeti dodatna vprašanja. Slovenski dodatek poizveduje o uporabniških izkušnjah z obstoječimi slovarji, konkretnih predlogih za izboljšave ter odnosu do množičenja $\mathrm{v}$ podporo slovaropisju. Rezultati tega dela ankete bodo obravnavani v ločenem prispevku, saj zaslužijo več prostora za interpretacijo in diskusijo. Tudi razpravo o namenu in formulaciji posameznih anketnih vprašanj in odgovorov gre prepustiti članom mreže ENeL, ki so vprašalnik oblikovali. V nadaljevanju kljub temu izpostavljamo nekatera problematična mesta, ki jih je razkrila podatkovna analiza. V luči opozoril, da je pri izvedbi uporabniških raziskav potrebno nameniti dovolj pozornosti zagotavljanju ustrezne interpretacije rezultatov (Logar idr. 2017), želimo na tak način omogočiti ustrezno branje in oblikovati izhodišča, ki lahko pri nadaljnjem razvoju metode anketnega raziskovanja

\footnotetext{
${ }^{1}$ Spletna stran: http://www.elexicography.eu/events/european-survey-on-dictionary-use/.
} 
uporabniških navad (in pri oblikovanju vprašalnikov) zagotovijo čim bolj objektivne rezultate.

V omenjenem smislu je treba vnaprej izpostaviti dve temi: prva se veže na zbiranje metapodatkov in strukturiranje anketnega vzorca, druga na razumevanje sodelujočih, o katerih jezikovnih priročnikih raziskava sploh sprašuje. Obe temi sta se namreč pokazali kot ključni pri anketnem načinu pridobivanja uporabniških mnenj, zato jima je tudi v nadaljevanju posvečene nekoliko več kritične pozornosti.

Mednarodna raziskava je v želji preseči dosedanje študije, ki so naslavljale majhne in povsem homogene skupine vprašanih, spodbudila nacionalne respondente $\mathrm{k}$ široki diseminaciji ankete. Uspešnost diseminacijskega dometa preverjajo vprašanja, $\mathrm{v}$ katerih sodelujoči opredeljujejo, $\mathrm{v}$ kolikšnem stiku so z jezikovnimi vprašanji v času službe/študija, koliko jih jezikovna problematika zanima in podobno. Zbiranje teh podatkov že v osnovi torej ni bilo namenjeno načrtovanemu vzorčenju po podskupinah, ampak omenjeni preverbi. Nizke zastopanosti posameznih (potencialnih) podskupin na ravni slovenskih podatkov tudi ne omogočajo statistično relevantnih primerjav, čeprav se bo možnost zanje morda ponudila na mednarodni ravni, kjer je numerus višji (9562 izpolnjenih anket v primerjavi s 619 slovenskimi). $\mathrm{V}$ tem prispevku se zato omejujemo na sintezo ugotovitev, v kateri so sodelujoči obravnavani kot celovita skupina (jezikovnih uporabnikov, ki niso nujno redni uporabniki konkretnih slovarskih priročnikov), obenem pa načrtujemo nadaljnje kvalitativne analize pri podskupinah, kjer se bo to izkazalo za relevantno.

Drugi omenjeni problem se povezuje s terminologijo in razumevanjem dometa ankete. V vprašalnik je vključena poljudna razlaga, da splošni enojezični slovarji (ang. general monolingual dictionaries) »pomen slovenskih besed opisujejo z razlagami v slovenščini, osredotočajo pa se na v rabi pogosto, splošno besedišče«. Že v strokovnem smislu ponujena definicija odpira 
vprašanja, katere slovenske slovarje točno anketa zajema, ${ }^{2}$ analiza rezultatov pa kaže, da so imeli z zamejevanjem težave tudi vprašani. Ko anketa sprašuje po splošnih enojezičnih slovarjih, ki jih sodelujoči uporabljajo, navaja za odgovor pet praznih mest. V mednarodnem kontekstu je to število smiselno, saj imajo številni jeziki na voljo večjo izbiro med slovarskimi priročniki. Za slovenski prostor pa je bilo število (pre)visoko in sodelujoči so razpoložljiva okenca zapolnjevali $\mathrm{z}$ zelo različnimi jezikovnimi viri, vse do korpusov in jezikovnotehnoloških orodij. Ker so na prva mesta sicer vnašali predvidene slovarje, kot sta SSKJ in SNB, je rezultat razumeti kot kombinacijo nepozornega branja vprašanja in zavajajočega števila praznih okenc za vnos. Zahteva pa poudarek, da je na izsledke treba gledati neodvisno od konkretnega obstoječega slovarskega vira, kar je $\mathrm{v}$ resnici skladno $\mathrm{z}$ namenom raziskave, ki ni evalvacijska (usmerjena $\mathrm{v}$ konkreten jezikovni vir $\mathrm{z}$ namenom njegove uporabniške ocene). $\mathrm{V}$ prvem koraku je uporabniško priročniško nevihtenje možganov lahko celo dobrodošlo, saj posredno razkriva dodatne probleme $\mathrm{v}$ razumevanju slovarja kot priročnika, k čemur se vračamo v nadaljevanju. Za morebitne ponovitve anketiranja $\mathrm{v}$ slovenskem prostoru pa bi bilo smiselno zavajajoči del vprašalnika spremeniti in domet jasneje opredeliti.

Vprašalnik kljub naštetim težavam zareže $\mathrm{v}$ problematiko, ki je v slovenskem (in najbrž ne le slovenskem) prostoru večplastna in pereča (gl. npr. Stabej 2009, Gorjanc idr. (ur.) 2015, Gorjanc 2017). Kot je bilo v literaturi že opozorjeno (npr. Rozman 2004, Stabej 2009, Logar 2009, Arhar Holdt 2015), v našem prostoru primanjkuje podatkov o navadah, potrebah in zmožnostih slovarskih uporabnikov, pa tudi jezikovnih težavah, ki govorce in govorke sploh usmerijo $\mathrm{k}$ rabi slovarjev. Poleg tega $\mathrm{v}$ zadnjih letih pospešeno raste zavedanje, da je vključevanje tako uporabniškega mnenja kot tudi sodelovalnega doprinosa,

\footnotetext{
${ }^{2} \mathrm{~V}$ prvi vrsti najbrž SSKJ (in SNB), ki pa v resnici ne prinaša nujno le »splošnega « besedišča. Slovarji, kot je SP 2001, se razlagam pomena posvečajo v manjši meri, vendar vsebujejo tudi pomenske informacije. Definicija tudi ne pove dosti o vrsti pomenskega opisa (je predpogoj sinhronost pogleda ali so vključeni etimološki slovarji), obsegu (so vključeni tudi slovarji v nastajanju) in referenčnosti (so vključene tudi kolaborativne pobude, kot je Razvezani jezik).
} 
pomemben del sodobnega digitalnega slovaropisja (npr. Kosem idr. 2013, Gorjanc idr. (ur.) 2015, Čibej idr. 2015, Arhar Holdt idr. 2016, 2017). V tej luči lahko pričujoči prispevek kljub omejitvam pomembno dopolni obstoječa spoznanja in nadaljuje prizadevanja na še vedno mladem področju slovenskih slovaropisnih uporabniških raziskav.

\section{PRIPRAVA ANKETE IN IZVEDBA ANKETIRANJA}

$\mathrm{V}$ bogatem naboru metodoloških možnosti za izvedbo slovaropisnih uporabniških raziskav (Welker 2013a, 2013b) je bilo za raziskavo izbrano spletno anketiranje. Vprašalnik, ki ga je pripravila jedrna skupina članov ENeL, 3 je bil preveden $v 26$ jezikov in diseminiran na ravni posameznih držav. Izbira diseminacijskih aktivnosti je bila prepuščena nacionalnim korespondentom, a s spodbudo, da se k sodelovanju povabi različne skupine potencialnih uporabnikov. Predhodnim študijam je bilo namreč očitano (npr. v Bogaards 2003, Tarp 2009, Müller Spitzer 2014), da zajemajo premajhno število udeležencev ali da je naslovljena skupina preveč homogena (pogosto $\mathrm{v}$ tovrstnih anketah sodelujejo predvsem študentje, ker so raziskovalcem najenostavneje dostopni).

Ker spletne ankete pridobijo predvsem mnenja posameznikov, ki so tudi sicer aktivni v digitalnem svetu, za sodelovanje pa se odločijo na osnovi lastne motivacije oz. interesa za anketno tematiko, verjetnostnega vzorčenja in s tem posploševanja na celotno populacijo s to metodo ni mogoče zagotoviti. Kljub temu je mogoče poskrbeti za objektivno, razpršeno in transparentno naslavljanje različnih potencialnih uporabniških skupin. $\mathrm{V}$ slovenskem prostoru smo pri strukturiranju seznama naslovnikov upoštevali shemo

\footnotetext{
3 Iztok Kosem (Filozofska fakulteta, Univerza v Ljubljani; Center za uporabno jezikoslovje, zavod Trojina), Carolin Müller-Spitzer (Institut für Deutsche Sprache), Robert Lew (Adam Mickiewicz University) in Sascha Wolfer (Institut für Deutsche Sprache).
} 
predvidenih slovarskih uporabnikov (Arhar Holdt 2015, Arhar Holdt idr. 2016), $\mathrm{v}$ povabilu $\mathrm{k}$ anketi pa je bilo posebej izpostavljeno, da je dragoceno tudi mnenje naslovnikov, ki slovarjev ne uporabljajo redno. Tabela 1 prinaša zgoščeni seznam skupin, ki so bile pri diseminaciji ekplicitno naslovljene.4

\section{Uporabniška skupina}

Izobraževanje: slovenščina kot prvi jezik (učitelji, dijaki); slovenščina kot drugi/tuji jezik (učitelji, tečajniki); študentje različnih smeri (jezikoslovnih in nejezikoslovnih)

Poklicne naloge: podjetja; jezikoslovci, razvijalci jezikovnih tehnologij; lektorji, prevajalci, novinarji, znanstveniki (nejezikoslovci), književniki, marketing, uradniki

Prosti čas: ugankarstvo, jezikovne igre, raziskovanje zanimivosti o jeziku, sporadična raba slovarja

\section{Naslovljeni}

Udeleženci Jezikovnotehnološkega izobraževanja učiteljev; Zavod za šolstvo; Andragoški center; udeleženci dijaških poletnih šol projekta Janes; Center za slovenščino kot drugi/tuji jezik; Cene Štupar; Univerzitetna služba za doktorski študij UL; Facebookova stran Univerze v Ljubljani; predavatelji, sodelujoči pri aktivnostih Centra za jezikovne vire in tehnologije, oz. njihovi študentje (FF UL, FRI UL, FDV UL, FHŠ UP, FKKT UM).

Ustanova patra Stanislava Škrabca, Združenje Menedžer, Krka, Amebis, Četrta pot, Rokus; poštni sezanami Slovlit in SDJT, Clarin.si; Lektorsko društvo

Slovenije; Društvo prevajalcev in tolmačev Slovenije, Prevajalski Studio, Facebookova skupina Prevajalci, na pomoč!; RTV, Radio Gorenc, Gorenjski glas; zaposleni

na FRI, FF in FDV UL; SLORI; PEN Mira, Društvo slovenskih pisateljev; Društvo za marketing Slovenije; Urad za komuniciranje RS, posamezna ministrstva RS.

Društvo Križemkražem; uporabniki Portala jezikovnih virov; Facebookovi skupini Društvo ljubiteljskih pravopisarjev in slovničarjev ter Za vsaj približno pravilno rabo slovenščine; Kvarkadabra; Med.over.net.

\footnotetext{
4 Kot je opozorjeno v uvodu, je shema osnova za diseminacijo ankete, vendar je ne gre enačiti s strukturo anketnega vzorca. $\mathrm{V}$ anketi zbrani metapodatki dokazujejo, da so bile v literaturi kritizirane prakse "pragmatičnega « dostopa do uporabnikov ustrezno presežene, v nadaljevanju anketiranja pa bi bilo smiselno vzorec še natančneje notranje uravnotežiti, tudi s pomočjo dodatnih vprašanj v slovenskem delu ankete.
} 
Tabela 1: Seznam neposredno naslovljenih uporabniških skupin.

Anketa je bila odprta med 9. majem in 9. julijem 2017. V tem času jo je izpolnilo 619 posameznic in posameznikov. Anketo je bilo mogoče izpolniti samo enkrat. Mediana za čas reševanja pri 591 udeležencih, ki so anketo rešili v strnjenem časovnem obdobju, je 12 minut in 22 sekund.5 $\mathrm{V}$ nadaljevanju navajamo rezultate po vsebinskih sklopih, čemur sledi strnitev glavnih izsledkov. Anketna vprašanja so navedena v naslovih slik in tabel.

\section{ANKETNI VZOREC}

\subsection{Starost, spol, izobrazba in prvi jezik vprašanih}

Med vključenimi posameznicami in posamezniki (v nadaljevanju: vprašanimi) prevladujejo rojeni v 70 -ih (22,9 \%), 80-ih (24,7 \%) in 90-ih (22,8 \%) letih prejšnjega stoletja. Sledijo rojeni v 6o-ih (16,8 \%) in 50-ih (7,6 \%), manj pa je mlajših (3,6 \%) in starejših (1,2 \%) vprašanih (Slika 1).

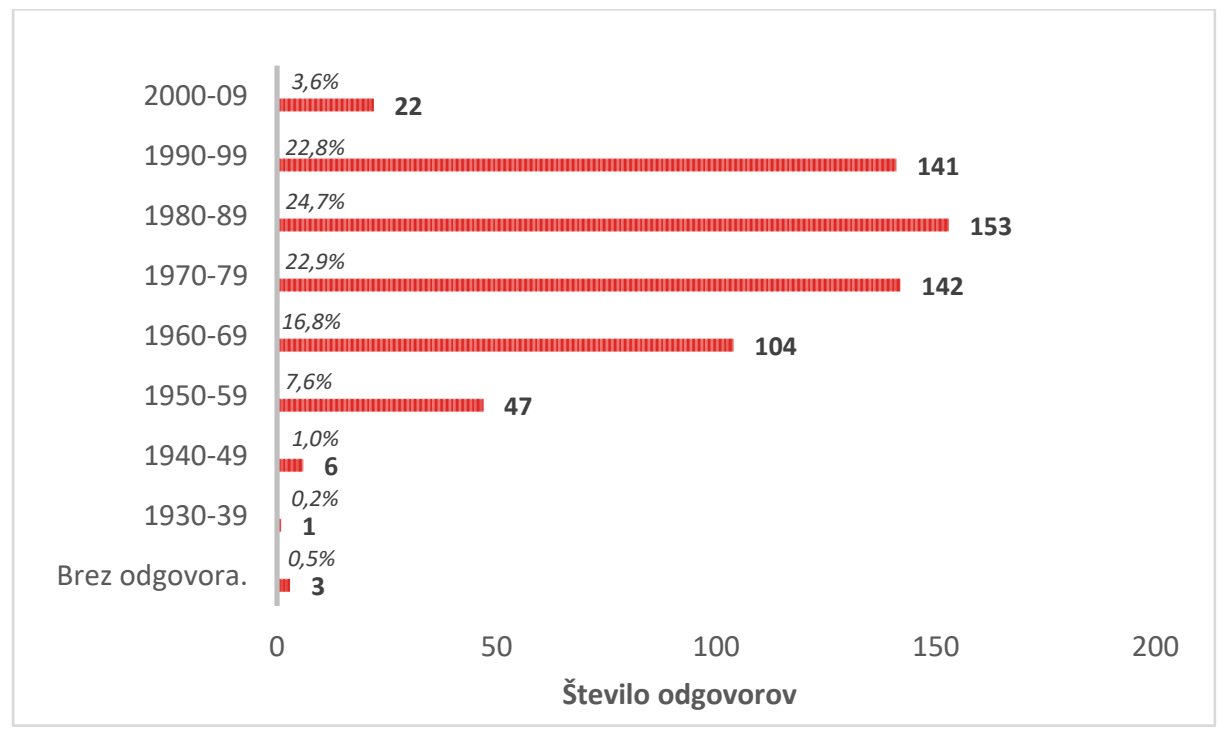

5 Povprečni čas (26 minut in 10 sekund) zaradi izrazitih osamelcev v podatkih ne daje realne informacije. Čas reševanja vključuje dodatni (samo slovenski) del ankete, ki obsega 6 vprašanj, od tega 3 odprtega tipa. 
Slika 1: Katerega leta ste rojeni?

Kot kaže Slika 2, je med vprašanimi več žensk (75,8 \%) kot moških (21,3 \%), brez odgovora na vprašanje o spolu pa je ostalo 18 anket (2,9 \%).

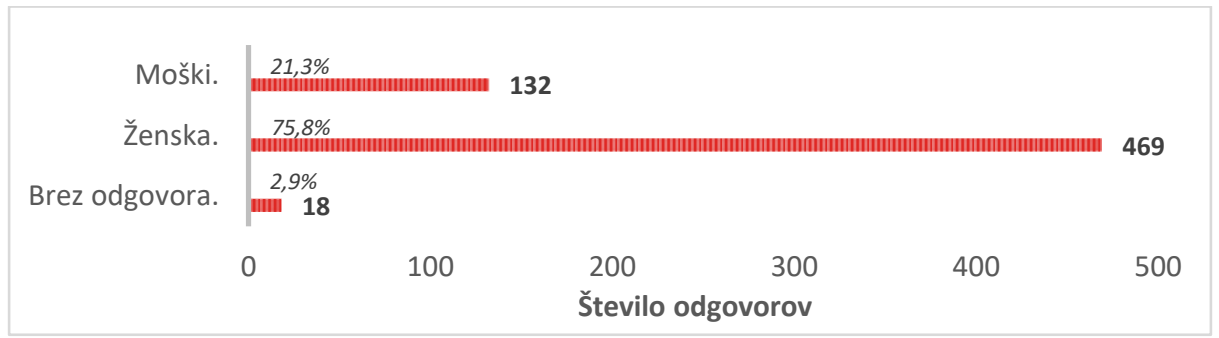

Slika 2: Vaš spol?

Najvišje število vprašanih ima 16 (21,8 \%) ali 17 (22,3 \%) let formalne izobrazbe, precej pa tudi med 18 in 20 let (skupno 23,3 \%) ali med 8 in 12 let (skupno 12 \%). Ostale izbire so redkejše, kot prikazuje Slika $3{ }^{6}$

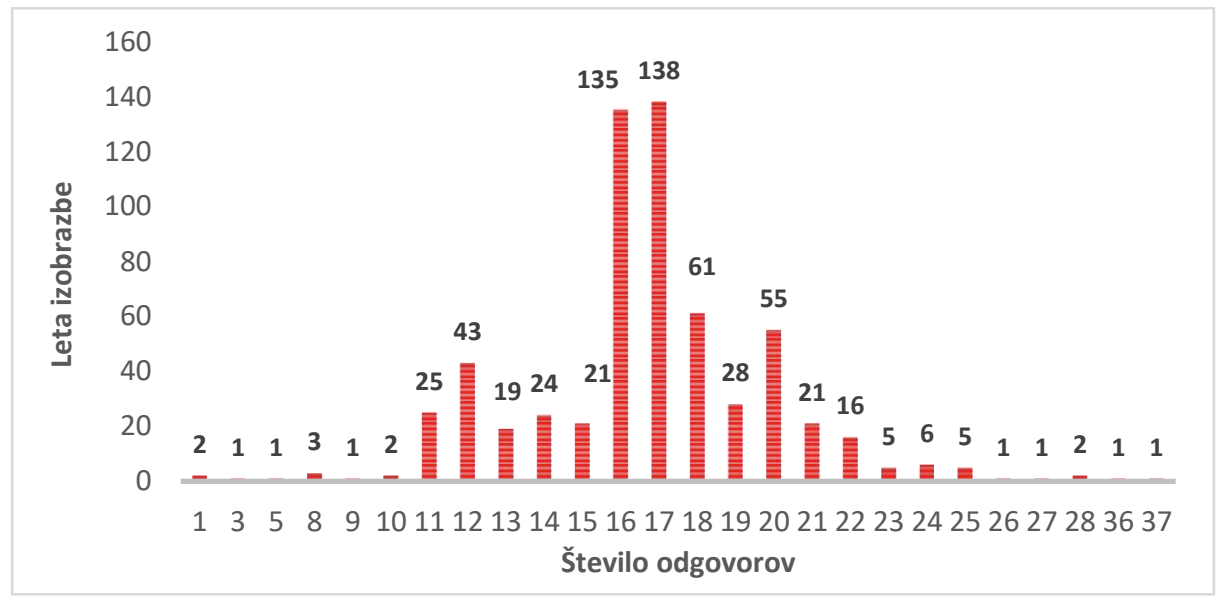

Slika 3: Koliko let formalne izobrazbe imate?

\footnotetext{
${ }^{6}$ Čeprav je pri določenih odgovorih, npr. pri izobrazbi ali prvem jeziku, mogoče dvomiti v verodostojnost - del teh odgovorov je vezan na mlajše udeležence, ki so anketo najbrž reševali po navodilu učitelja - podatkov nismo izključevali iz nadaljnje analize.
} 
Pri večini vprašanih (585) je bil kot prvi jezik izbran slovenski, nekaj pa je tudi drugih izbir, npr. hrvaški in slovaški (po 7),7 srbski in italijanski (po 3) ter kitajski, arabski, turški, poljski, francoski in češki (po 1). 8 vprašanih je opredelilo, da njihov prvi jezik med ponujenimi izbirami ni na voljo (na spustnem seznamu je bilo na izbiro 44 jezikov in možnost, da jezik ni na voljo).

\subsection{Poklic, povezanost študija/dela $z$ jeziko(slo)vnimi temami}

Kot kaže Slika 4, je večina vprašanih zaposlena v javni ali zasebni organizaciji oz. podjetju (56,7 \%), sledijo študenti prve in druge stopnje (skupno 17,5\%), učenci oz. dijaki (10,5\%) in samozaposleni (8,2 \%). Manj je upokojenih in brezposelnih (po 2,4 \%) ter vzdrževalcev gospodinjstva in vajencev (po o,2 \%).

\footnotetext{
7 Vprašani so jezik izbrali s pomočjo abecednega spustnega menija, v katerem je slovenščina umeščena ob slovaščino, možne so napake pri izbiri.
} 


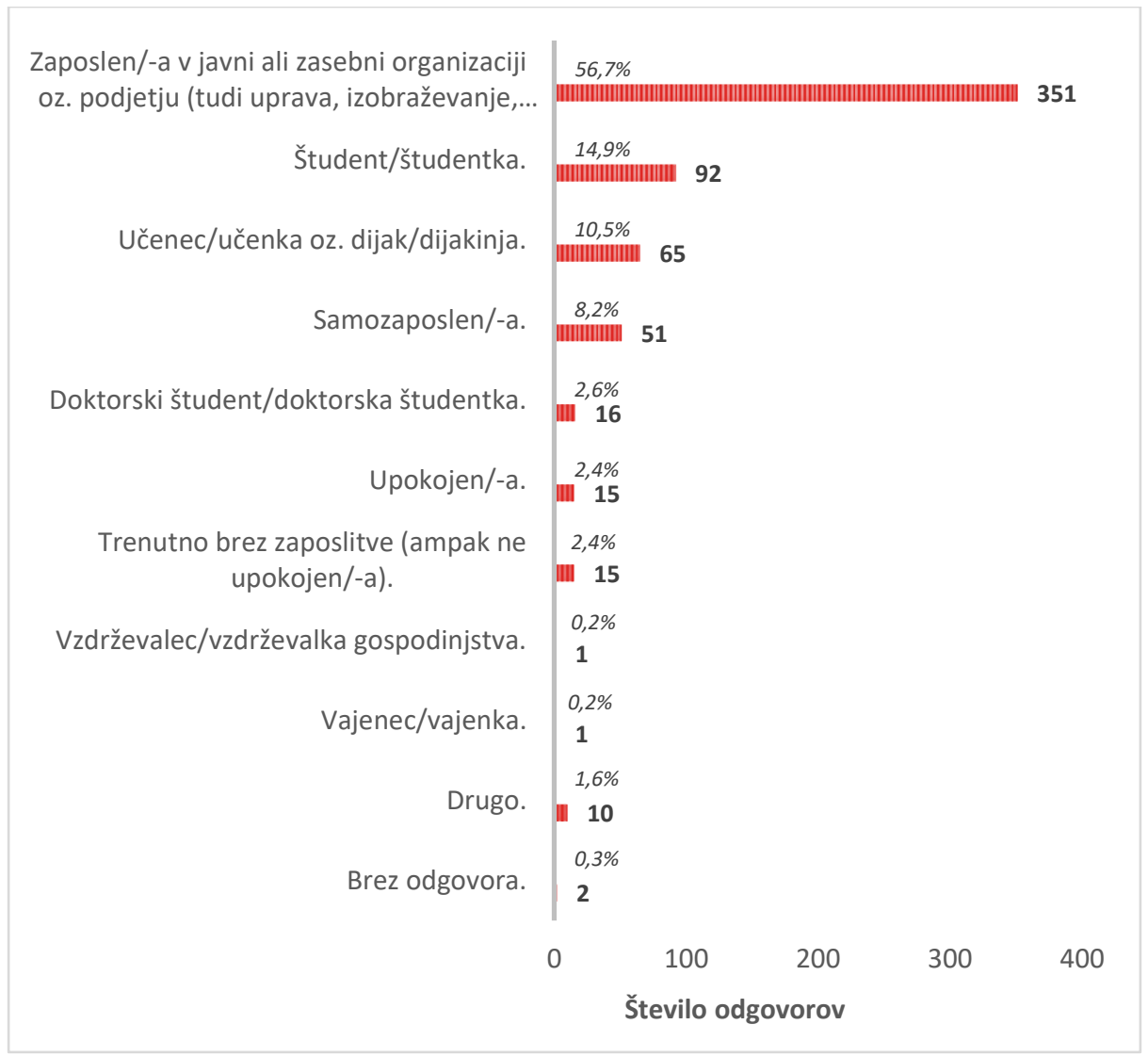

Slika 4: Katera od možnosti najbolje opiše vašo trenutno zaposlitveno situacijo? Vprašani so opredelili, koliko so jeziko(slo)vna vprašanja povezana z njihovimi poklicnimi, študijskimi in zasebnimi interesi. Slika 5 kaže, da je med vprašanimi velik delež univerzitetno izobraženih na področju, kjer jezik igra pomembno vlogo (74 \%). Slika 6 kaže, da se večina vprašanih v službi aktivno ukvarja z jezikovnimi vprašanji (81,9 \%) in Slika 7 , da jo jezik posebej zanima (80,1 \%). Slika 8 kaže, da je učiteljev jezika med vprašanimi 27,8 \%. 


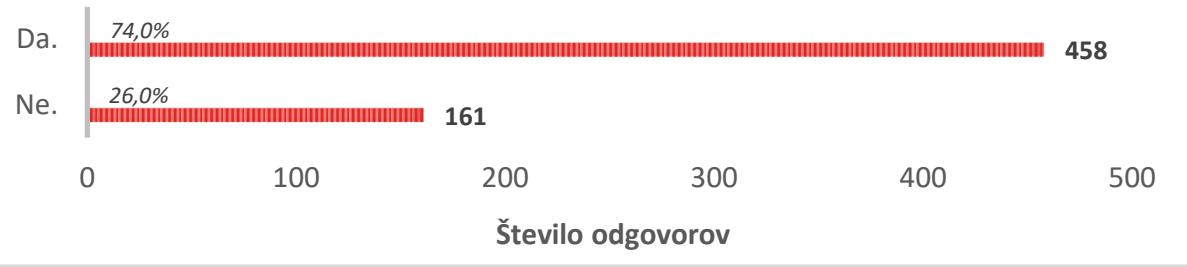

Slika 5: Ste univerzitetno izobraženi oz. se izobražujete na področju, kjer igra pomembno vlogo jezik oz. jezikoslovje?

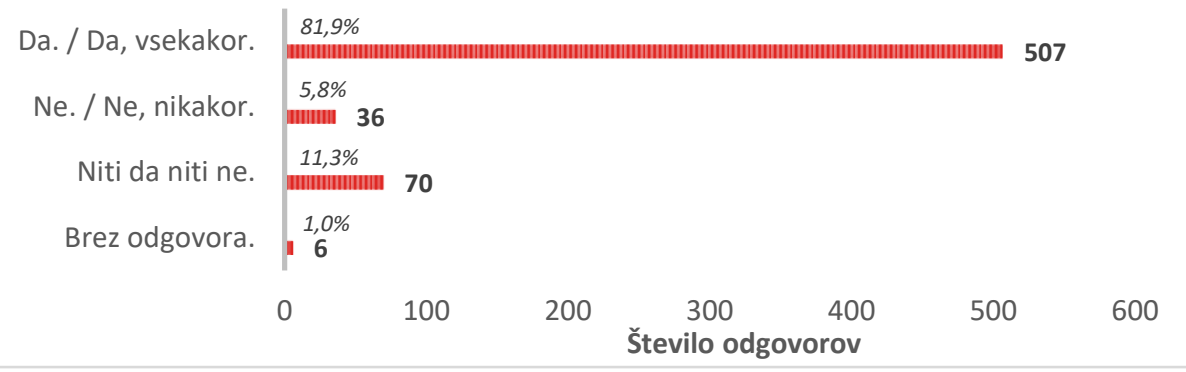

Slika 6: Ali v službi veliko pozornosti posvečate jeziku (bodisi slovenščini ali drugim jezikom)?

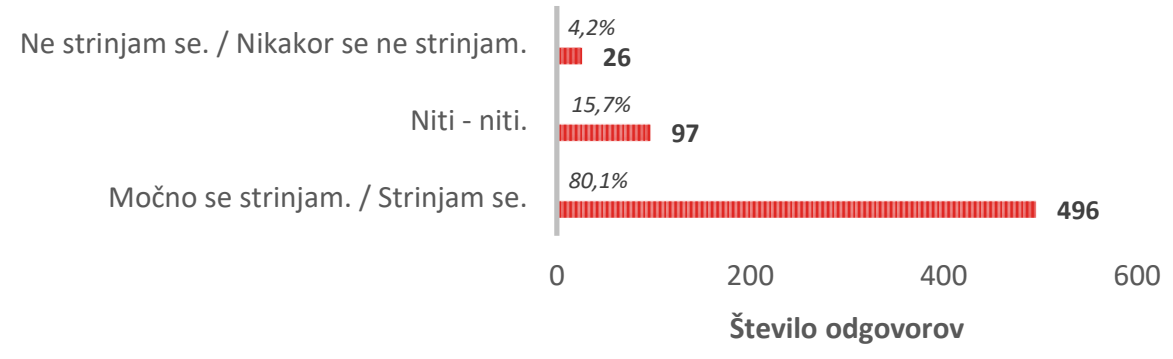

Slika 7: Bi rekli, da vas jezik zaradi določenega razloga posebej zanima? 


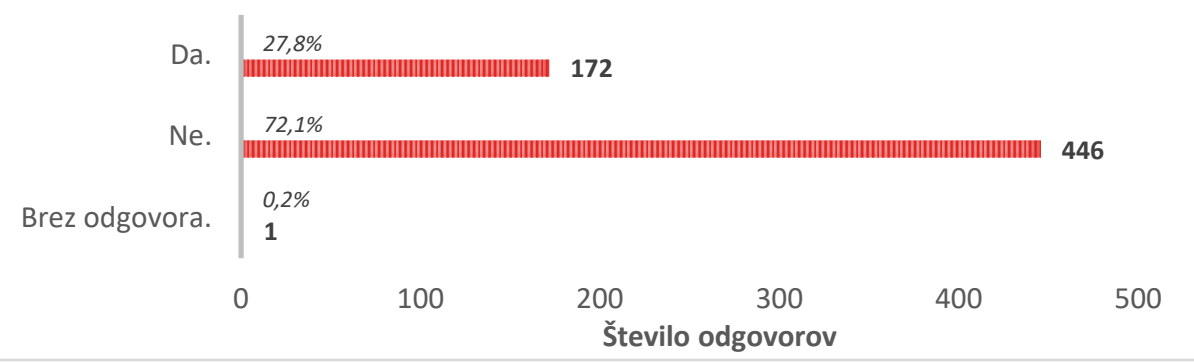

Slika 8: Ste učitelj/-ica jezika?

\subsection{Spletna prisotnost in uporaba naprav}

Vprašani so posredovali oceno, koliko ur dnevno običajno preživijo na spletu. Podatki (Slika 9) kažejo, da jih največji delež (skupno 73 \%) preživi na spletu od 1 do 5 ur dnevno, med 6 in 12 ur dnevno je na spletu skupno 23 \% vprašanih, pojavljajo pa se tudi višje in nižje ocene, ki pričajo o morebitni dvoumnosti vprašanja. Slika 10 kaže, katere naprave vprašani uporabljajo na dnevni ravni (možno je bilo izbrati več odgovorov): večina pametni telefon (84,3 \%), sledita prenosnik (69,3\%) ali namizni računalnik (61,1\%) in redkeje tablica (20,5\%).

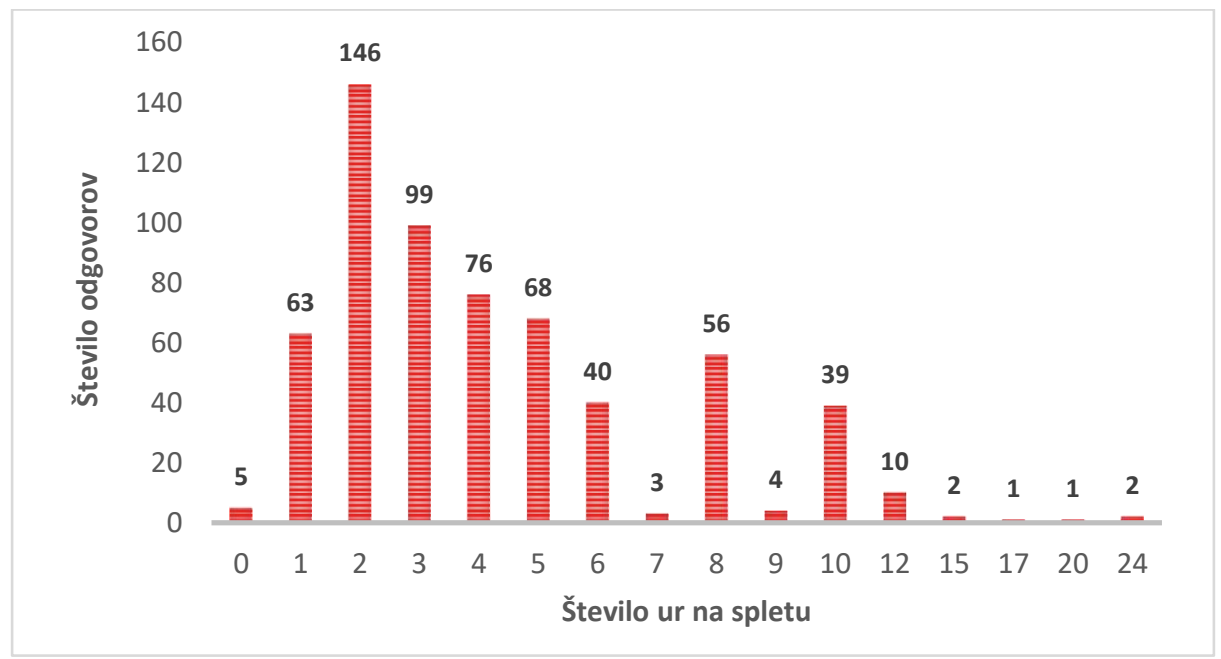

Slika 9: Koliko ur dnevno preživite na spletu? 


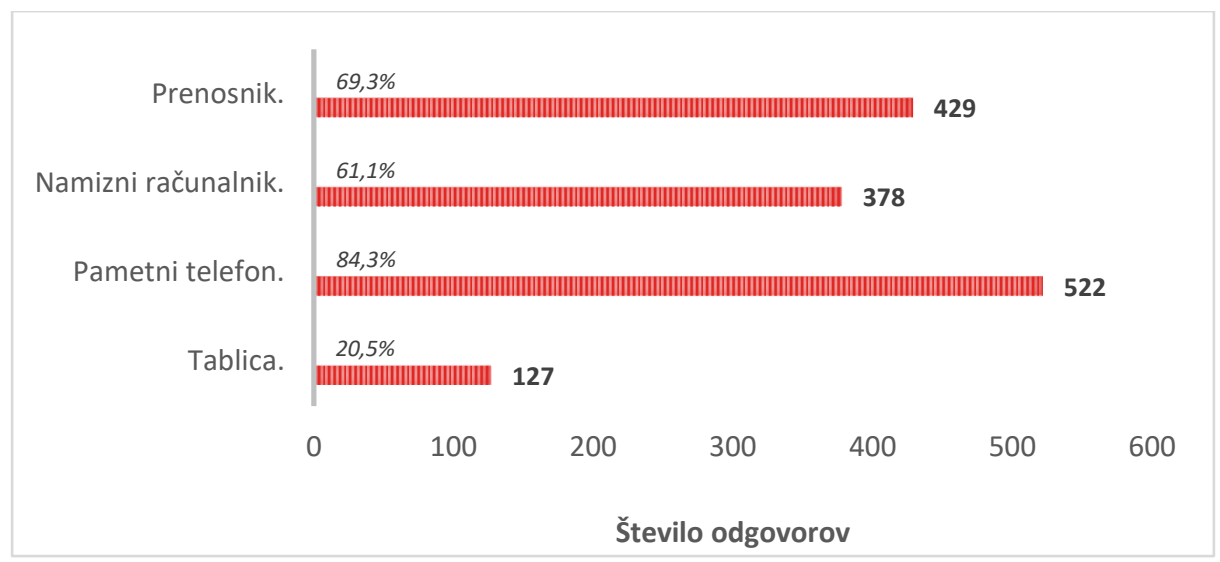

Slika 10: Označite vse naprave, ki jih dnevno uporabljate.

\section{REZULTATI}

\subsection{Slovarji v rabi}

Anketa v prvem koraku preverja, kako pogosto vprašani uporabljajo slovarje. Kot omenjeno v uvodu, sledi razlaga, da splošni enojezični slovarji slovenščine »opisujejo pomen slovenskih besed z razlagami v slovenščini in se osredotočajo na v rabi pogosto, splošno besedišče«, nato še natančneje vprašanje, kako pogosto vprašani uporabljajo enojezične slovarje slovenščine. ${ }^{8}$ Slika 11 kaže, da je v tednu pred izpolnjevanjem ankete (katerikoli) slovar vsaj enkrat uporabilo 75,2 \% vprašanih, med njimi je 51,9 \% takih, ki so slovar uporabili na dan reševanja ankete ali dan pred tem. (Katerikoli) enojezični slovar slovenščine je v tednu pred izpolnjevanjem ankete vsaj enkrat uporabilo 58,9 \% vprašanih, od tega $35,5 \%$ na dan reševanja ankete ali dan pred tem. Ostale kategorije nakazujejo bolj sporadično slovarsko rabo. V mesecu pred anketo je katerikoli

\footnotetext{
8 Definicija vsebuje tudi opredelitev, da gre za splošne slovarje, v vprašalniku pa se v nadaljevanju večinoma govori le o enojezičnosti (npr. When was the last time you used a monolingual dictionary of English?). Zaradi zagotavljanja mednarodne primerljivosti rezultatov slovenski prevod sledi izvirniku, identificirane težave pri razumevanju dometa raziskave pa nakazujejo potrebo, da se za lokalno rabo vprašalnik pred morebitnimi ponovnimi izvedbami terminološko premisli in prilagodi.
} 
slovar uporabilo 13,2 \% vprašanih, slovenskega enojezičnega 17,1 \%. V letu pred anketo je katerikoli slovar uporabilo 7,1 \%, slovenskega enojezičnega 13,9 \% vprašanih. Ostali vprašani slovarje uporabljajo še redkeje ali sploh ne. V to skupino se glede rabe kateregakoli slovarja uvršča 4,5 \% vprašanih, glede slovenskega enojezičnega pa $10 \%$ vprašanih.

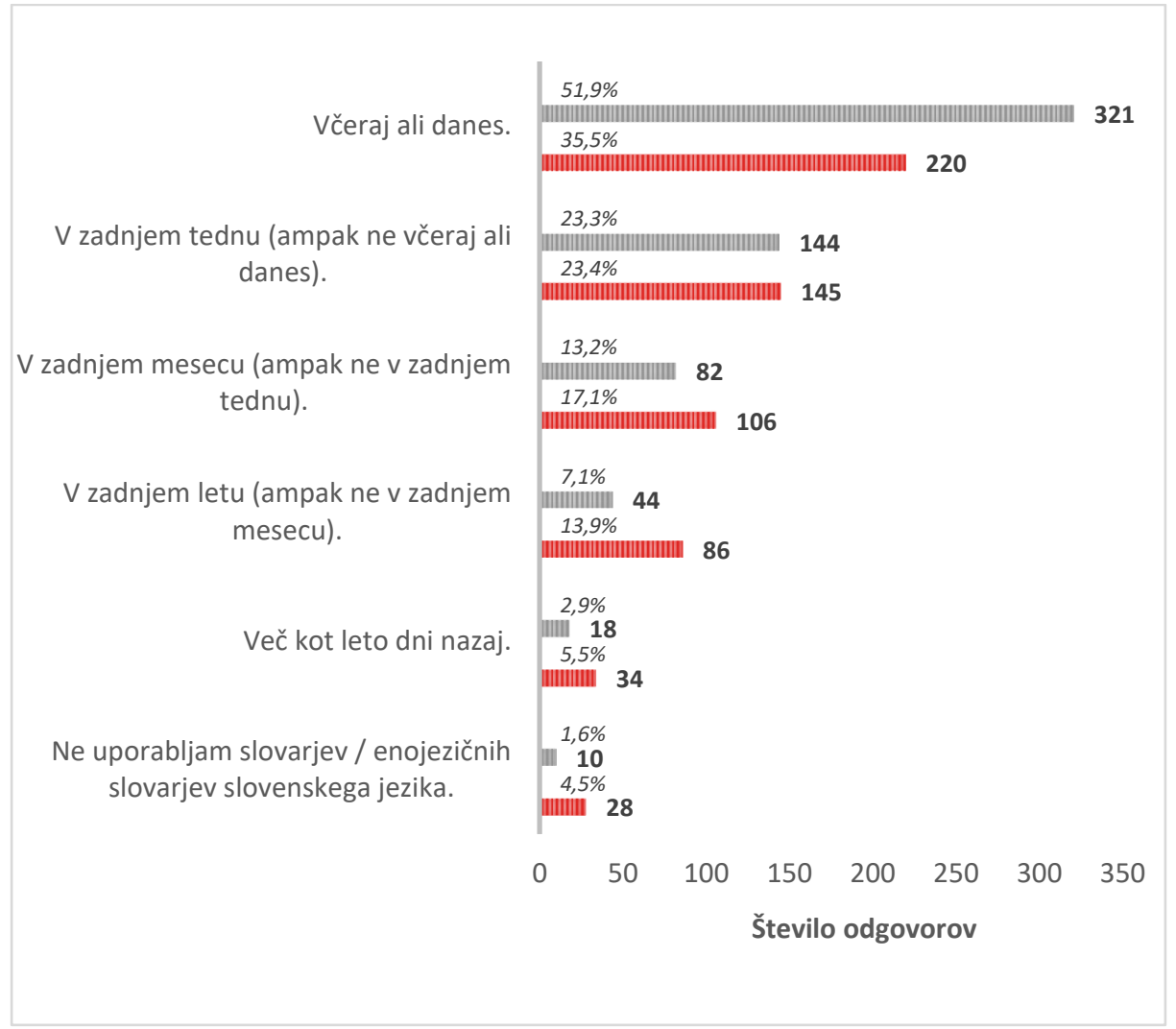

Slika 11: Kdaj ste nazadnje uporabili slovar (siva barva na sliki)? Kdaj ste nazadnje uporabili enojezični slovar slovenščine (rdeča barva na sliki)?

Vprašani so nato opredelili, katere splošne enojezične slovarje za slovenščino uporabljajo, za kar je bilo na voljo pet razdelkov za vnos besedila. Vprašani so skupno vnesli 1185 odgovorov: 41,7 \% vprašanih je vneslo po en vir, 18,9 \% po dva, $13,7 \%$ po tri, $7,6 \%$ po štiri in $8,0 \%$ po pet. 10 \% vprašanih na vprašanje ni odgovarjalo. Vprašani, ki so slovarje uporabili pred kratkim, so pogosto 
podajali več odgovorov, sporadični uporabniki pa po enega ali pa so pustili razdelek prazen. Vnesene jezikovne vire smo kodirali glede na vrsto ${ }^{9}$ (Tabela 2). Kot je problematizirano v uvodu, odgovori razkrivajo težave sodelujočih pri razumevanju vprašanja in posredno dometa raziskave, zato je vse rezultate treba razumeti s to predpostavko. Odgovori, ki so pogosto v obliki spletne povezave na določen vir, pa razkrivajo dodatna mesta raziskovalnega interesa, npr. glede potencialno problematičnega razumevanja slovarskih iskalnikov (Fran, Termania) kot enovite (slovarske) celote. ${ }^{10}$

\begin{tabular}{l|r|r}
\hline Kategorija navedenega vira & Stevilo odgovorov & Delež \\
\hline SSKJ & 521 & $84,2 \%$ \\
\hline Fran & 145 & $23,4 \%$ \\
\hline SP 20oo & 131 & $21,2 \%$ \\
\hline etimološki slovarji & 78 & $12,6 \%$ \\
\hline SNB & 49 & $7,9 \%$ \\
\hline slovarji tujk & 42 & $6,8 \%$ \\
\hline terminološki slovarji & 40 & $6,5 \%$ \\
\hline frazeološki slovarji & 40 & $6,5 \%$ \\
\hline slovarji sopomenk & 25 & $4,0 \%$ \\
\hline tuji enojezični, dvojezični, prevajalniki & 25 & $4,0 \%$ \\
\hline Termania, ASP 32 & 19 & $3,1 \%$ \\
\hline korpusi & 12 & $1,9 \%$ \\
\hline drugo & 11 & $1,8 \%$ \\
\hline Besedišče, Besede, bos.zrc-sazu & 9 & $1,5 \%$ \\
\hline
\end{tabular}

9 Če je zapis vseboval več kot en vir (Vse, kar je vključeno $v$ Fran in Termanio), je bil v stolpcu podvojen in pripisani sta bili dve kategoriji.

${ }^{10}$ Kot je razvidno iz deležev, so nekateri uporabniki SSKJ in portal Fran navajali tudi ločeno. Rezultati osvetljujejo, da raznolikost in hibridnost dostopnih možnosti, ki so povezane z digitalnim medijem, vplivata na dojemanje same sestave virov, posledično pa morda tudi na interpretacijo $\mathrm{v}$ njih najdenih rezultatov. Ta izsledek je mogoče uporabiti za nadaljnje oblikovanje raziskovalnega vprašalnika. 


\begin{tabular}{l|r|r}
\hline Razvezani jezik & 8 & $1,3 \%$ \\
\hline Pleteršnik, Glonar & 7 & $1,1 \%$ \\
\hline $\begin{array}{l}\text { Vezljivostni slovar, Odzadnji slovar, } \\
\text { Slovar členkov }\end{array}$ & 7 & $1,1 \%$ \\
\hline leksikoni besednih oblik & 6 & $1,0 \%$ \\
\hline Sprotni slovar & 6 & $1,0 \%$ \\
\hline Slovar pravopisnih težav & 6 & $1,0 \%$ \\
\hline LBS, drugi rezultati projekta SSJ & 5 & $0,8 \%$ \\
\hline
\end{tabular}

Tabela 2: Katere enojezične slovarje slovenskega jezika uporabljate?

\subsection{Situacije slovarske rabe}

V anketo je bilo vključeno vprašanje, v katerih situacijah so vprašani že kdaj uporabili oz. uporabljajo enojezični slovar slovenščine. Izbrati je bilo mogoče več odgovorov (Slika 12). Največ vprašanih je odgovorilo, da slovar uporabljajo za preverbo slišanih ali prebranih besed $(74,5 \%),{ }^{11}$ za pripravo službenih ali študijskih besedil (73 \%) in za preverbo v situacijah, kadar se s kom ne strinjajo glede rabe (67\%). Več kot pol vprašanih slovar uporablja za popravljanje besedil drugih (57,5 \%), manj kot pol pa ob pripravi besedil, kot je življenjepis (44,7 \%), za branje knjig, časopisov, blogov (30,5\%) ter uradnih dokumentov (28,9 \%). Redkejša je raba slovarja za kreativno pisanje (26 \%), pisanje računalniško posredovanih sporočil (25 \%) in za ugankarstvo in jezikovne igre (24,7 \%). V kategoriji Drugo (16 \%) so vprašani navajali predvsem rabo slovarja za prevajanje ter izvedbo raziskav. Da imajo najpogostejši štirje odgovori posebno težo, nakazuje podatek, da se med kombinacijami različnih odgovorov najpogosteje pojavi ravno kombinirana izbira le-teh (pri 14 vprašanih);

\footnotetext{
${ }^{11}$ Prevod vprašalnika ohranja širino vprašanja v izvirniku (Checking a word that I've heard or read), kjer ni povsem jasno, ali gre za preverbo pomena, obstoja ali ustreznosti zapisa besede ali česa četrtega, kar je s stališča interpretacije rezultatov lahko problematično (več o tem v diskusiji, kjer so odgovori razvrščeni glede na vezanost na jezikovno recepcijo in produkcijo).
} 
vprašani, ki so se odločili za en sam odgovor, pa so najpogosteje izbrali, da uporabljajo slovar za preverbo slišanih oz. prebranih besed (14 vprašanih).

Da preverim besedo, ki sem jo slišal/-a ali prebral/-a.

Za pripravo besedil, ki so del službenih nalog ali izobraževalnega procesa (poročila, domače naloge, seminarske naloge ipd.).

Kadar se s kom ne strinjam glede rabe.

Za popravljanje besedil, ki so jih napisali drugi.

Za pisanje pomembnih besedil (prijava na delovno mesto, življenjepis ipd.).

Ob branju knjig, revij, časopisov, blogov ipd.

Ob branju uradnih dokumentov.

Za kreativno pisanje (poezija, besedila pesmi, zgodbe ipd.).

Za pisanje e-sporočil in spletnih objav (na forumih/blogih/družbenih omrežjih ...) ali pisem ipd.

Za ugankarstvo in jezikovne igre (križanke, Scrabble ipd.).

V drugih situacijah.

Brez odgovora.
$74,5 \%$

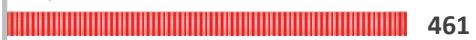

$73,0 \%$

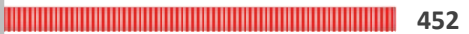

$67,0 \%$

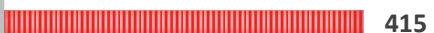

$57,5 \%$

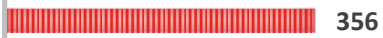

$44,7 \%$

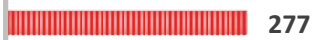

$30,5 \%$

|||||||||||||||||||||||||||||| 189

$28,9 \%$

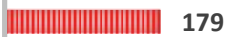

$26,0 \%$

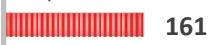

$25,0 \%$

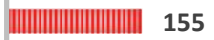

$24,7 \%$

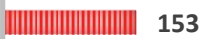

$16,0 \%$

|||||||||||||||| 99

\section{6}

277

179

$4,5 \%$

28

0

Slika 12: V kateri od naštetih situacij ste že kdaj uporabili oz. uporabljate enojezični slovar slovenščine? 


\subsection{Pomen slovarja za skupnost in posameznika}

$\mathrm{V}$ anketo je bilo vključenih več vprašanj o pomenu slovarja za skupnost in posameznika. V prvem od njih so vprašani opredelili, kaj po njihovem mnenju ljudem predstavlja enojezični slovar. ${ }^{12}$ Vprašani so lahko izbrali več odgovorov (Slika 13).

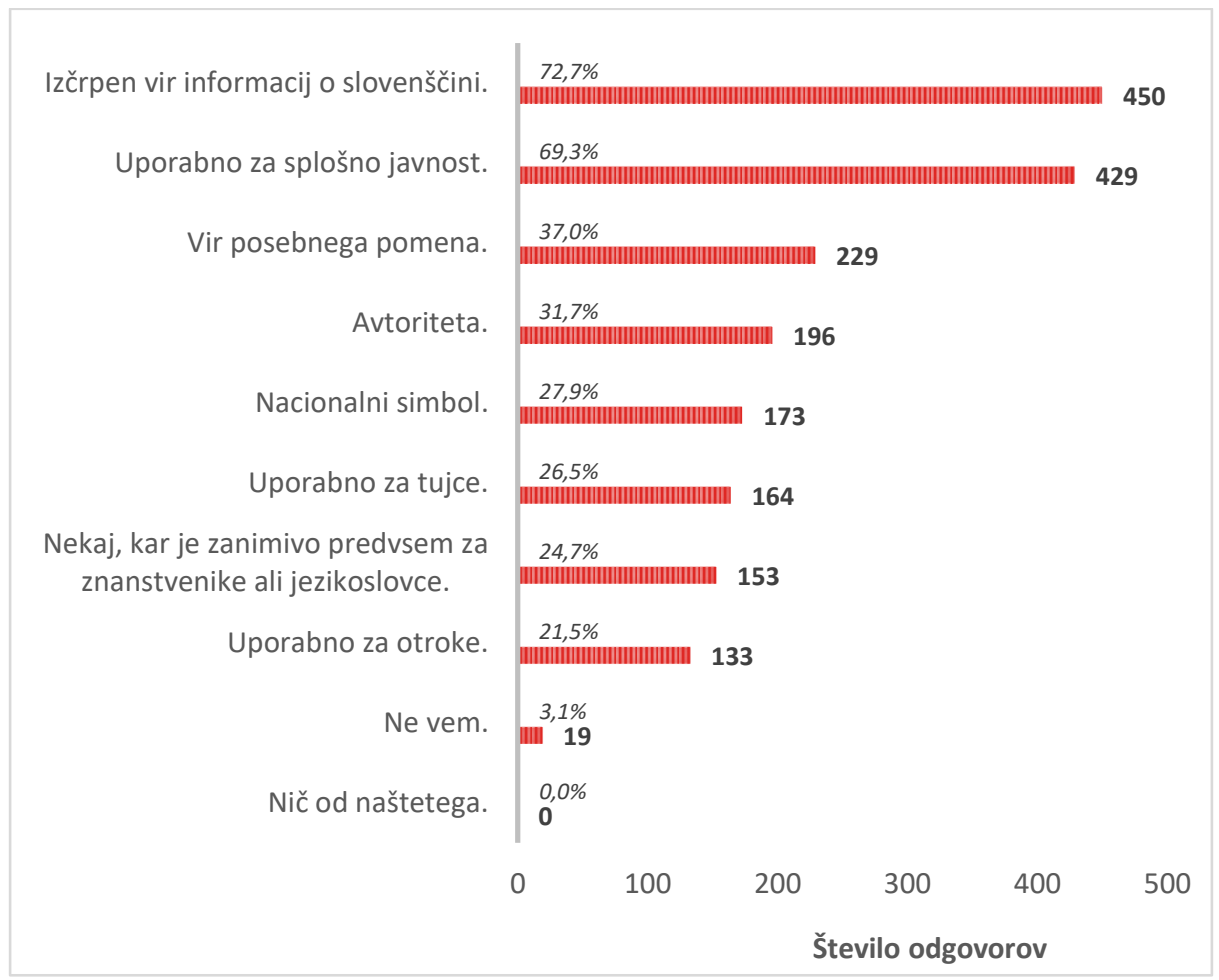

Slika 13: Kaj od naštetega (po vašem mnenju) ljudem predstavlja enojezični slovar slovenskega jezika?

Med najpogosteje izbranimi sta trditvi, da slovar predstavlja izčrpen vir informacij o slovenščini (72,7 \%) in da je uporaben za splošno javnost (69,3 \%). Redkeje se pojavljajo ocene, da gre za vir posebnega pomena (37\%), avtoriteto

12 Analiza rezultatov kaže, da bi bilo transparentneje za interpretacijo, če bi vprašanje sodelujoče spraševalo, kaj slovar predstavlja njim osebno (več o tem v diskusiji). 
(31,7 \%) ali nacionalni simbol (27,9\%). Najredkeje pa so izbrane trditve, da je slovar zanimiv predvsem za jezikoslovce (24,7 \%) ali uporaben za otroke $(21,5$ \%). Vprašani, ki so izbrali samo en pomen, so največkrat izbrali ‘izčrpen vir informacij' (34 vprašanih) ali 'uporabno za splošno javnost' (33 vprašanih), tudi med kombinacijami je najpogostejša ravno izbira teh dveh odgovorov (53 vprašanih).

Pri vprašanju, kaj bi naredili, če bi pri urejanju sorodnikove zapuščine našli znan enojezični slovar, je bilo možno izbrati samo en odgovor (Slika 14). Večina vprašanih (81,4 \%) bi slovar obdržala: 51,1 \% zato, da bi slovar uporabljali, 23,4 \% zato, ker je bil last sorodnika, in 6,9 \% vprašanih zato, ker bi dobro izgledal na knjižni polici. Manjši delež vprašanih bi slovar podaril knjižnici (9,4 \%) ali skušal prodati (3,1 \%), izjemno redko izbrana pa je bila možnost, da bi slovar vrgli v smeti oz. dali v reciklažo $(0,8 \%)$.

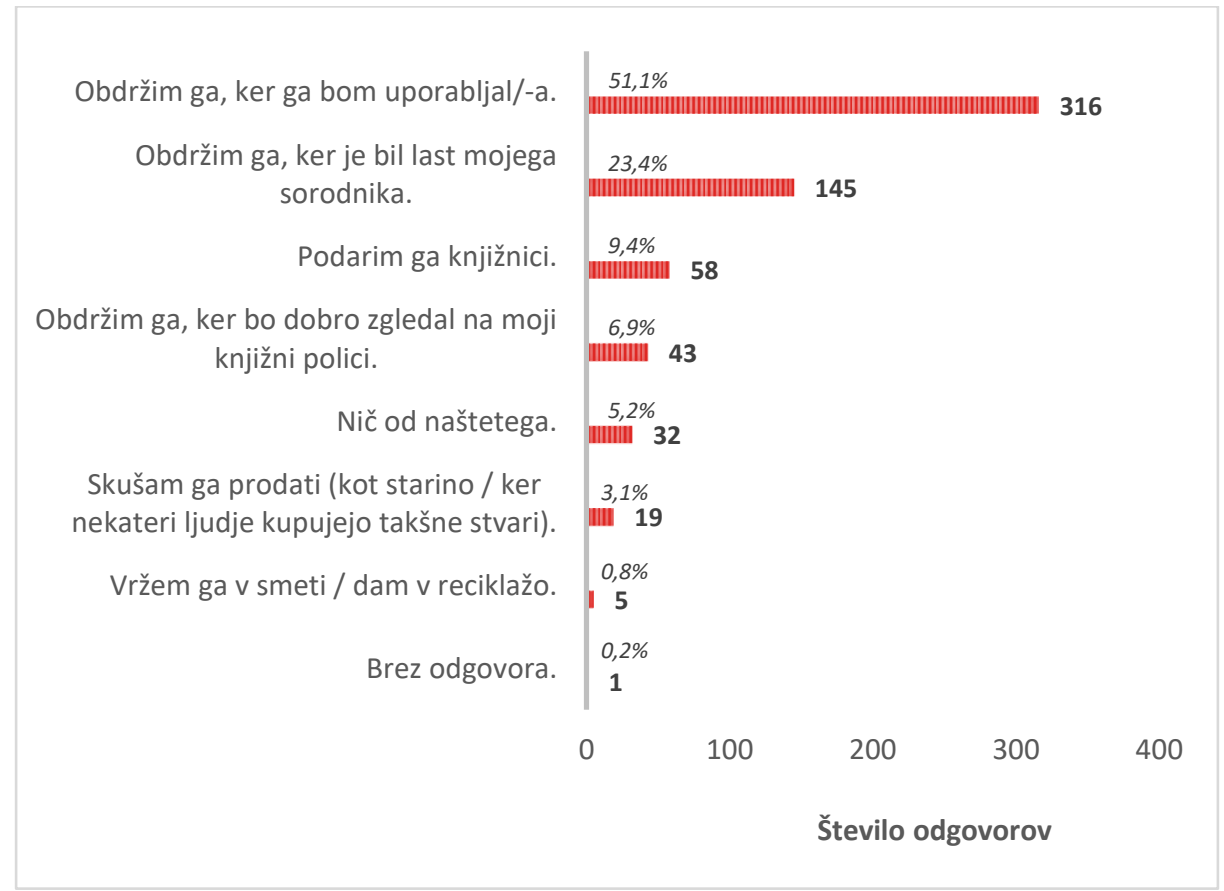

Slika 14: Predstavljajte si naslednjo situacijo: ob urejanju sorodnikove zapuščine najdete znan enojezični slovar. Kaj storite? 
Zadnje vprašanje je poizvedovalo, kako vprašani ukrepajo, če v slovarju določene besede ne najdejo. Večina se $\mathrm{v}$ tovrstnih situacijah zateče na splet (79,8 \%) ali v kak drug, sodobnejši vir (59,3 \%). Skoraj polovica se obrne za mnenje na druge ljudi (44,3\%). Vprašanih, ki neobstoj besede v slovarju pripisujejo redkosti v rabi, je 24,7 \%, tistih, ki neobstoj interpretirajo kot da očitno ne gre za »pravo besedo«, pa je $11 \%$. Rezultate kaže Slika 15.

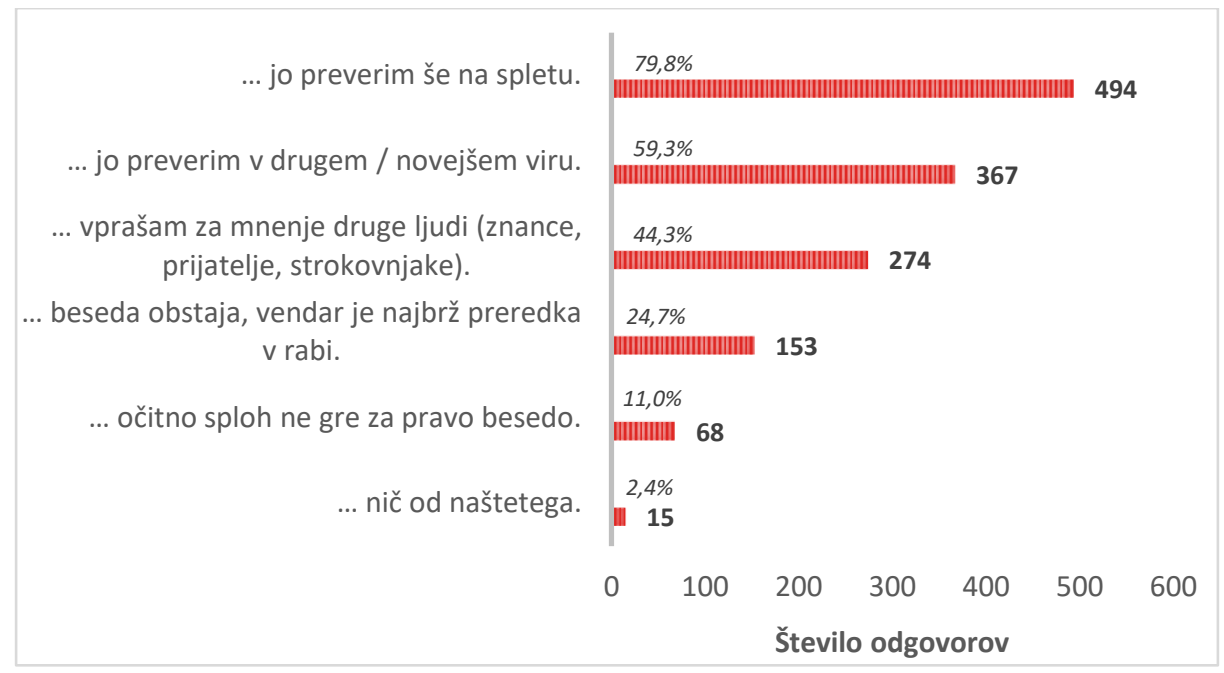

Slika 15: Kadar naletim na besedo, ki v enojezičnem slovarju ne obstaja, ...

\subsection{Financiranje slovarja}

Anketa je spraševala, ali vprašani podpirajo javno financiranje izdelave splošnih enojezičnih slovarjev, koliko so sicer pripravljeni plačati za slovar in ali pristajajo na vključitev oglasov v slovarski prostor. Na prvo od naštetih vprašanj (Slika 16) so skoraj vsi vprašani odgovorili pritrdilno: 96,1 \% jih je mnenja, da je pripravo splošnih enojezičnih slovarjev smiselno financirati iz javnega denarja. Med razlogi za javno financiranje so vprašani najpogosteje izbrali, da so slovarji temeljni del kulturne dediščine (49,9 \%) in da v končni fazi pomagajo javnosti (37,8 \%). Med sicer redkimi razlogi proti (skupno 3,9 \%) prevladuje vprašanje prioritet javnega financiranja (1,6 \%). Tako pri razlogih za 
kot proti javnemu financiranju je bilo mogoče označiti, da pravi razlog med podanimi odgovori ni naštet, to možnost je skupno izbralo $6,5 \%$ vprašanih.

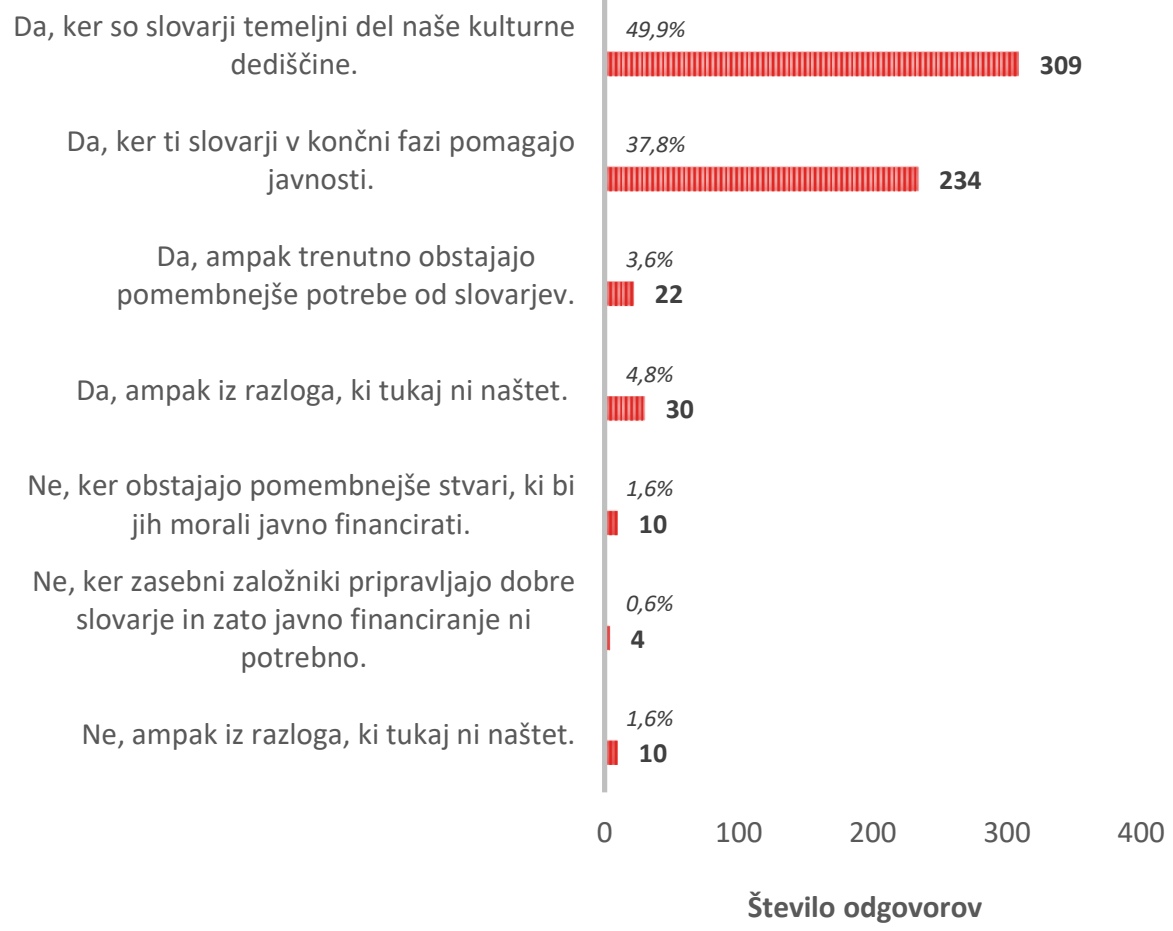

Da, ker ti slovarji v končni fazi pomagajo javnosti.

Da, ampak trenutno obstajajo pomembnejše potrebe od slovarjev.

Da, ampak iz razloga, ki tukaj ni naštet.

$\mathrm{Ne}$, ker obstajajo pomembnejše stvari, ki bi jih morali javno financirati.

$\mathrm{Ne}$, ker zasebni založniki pripravljajo dobre slovarje in zato javno financiranje ni potrebno.

Ne, ampak iz razloga, ki tukaj ni naštet.

Slika 16: Priprava enojezičnih slovarjev je pogosto financirana iz javnega denarja. Se vam zdi to smiselno?

V nadaljevanju so vprašani opredelili, koliko so pripravljeni plačati za slovar v različnih oblikah (tiskani slovar, namizna aplikacija, spletni slovar in mobilna aplikacija). Rezultate prikazuje Tabela 3. Po pričakovanjih se pri tem vprašanju pojavlja nekoliko višji delež vprašanih, ki niso znali ali želeli posredovati odgovora (med 13,4 in 15,7 \%). Vprašanje je vsebovalo navodilo, da v primeru nepripravljenosti plačati za slovar sodelujoči vnesejo vsoto o EUR. Ti podatki so v tabeli navedeni v ločenem stolpcu: za tiskani slovar ni pripravljenih plačati 25,7 \% vprašanih, za namiznega 42,0 \%, za spletnega 50,1 \% in za mobilno 
aplikacijo 55,6 \%. Ostali vprašani so navajali vrednosti v razponu med 1 in 1000 EUR z izrazitimi podatkovnimi osamelci (tj. izstopajočimi vrednostmi), zato Tabela 3 poleg aritmetične sredine navaja tudi mediano in modus. Če srednje vrednosti izračunamo le za vprašane, ki so za slovar pripravljeni plačati, se gibljejo med 50 in 61,7 EUR za tiskano različico slovarja, med 20 in 34,5 EUR za namizno, med 20 in 36,7 EUR za spletni slovar ter med 5 in 20,3 EUR za mobilno aplikacijo.

\begin{tabular}{l|l|l|l|l}
\hline Vrsta & $\begin{array}{l}\text { Brez } \\
\text { odgovora }\end{array}$ & o EUR & $\begin{array}{l}\text { Mediana/modus } \\
\text { /aritm. sredina } \\
\text { za vse podatke }\end{array}$ & $\begin{array}{l}\text { Mediana/modus } \\
\text { /aritm. sredina } \\
\text { brez 'o EUR' }\end{array}$ \\
\hline $\begin{array}{l}\text { Tiskani } \\
\text { slovar }\end{array}$ & $\begin{array}{l}83 \\
(13,4 \%)\end{array}$ & $\begin{array}{l}159 \\
(25,7 \%)\end{array}$ & $30 / 0 / 43,4$ EUR & $50 / 50 / 61,7$ EUR \\
\hline $\begin{array}{l}\text { Slovar kot } \\
\text { namizna } \\
\text { aplikacija }\end{array}$ & $\begin{array}{l}95 \\
(15,3 \%)\end{array}$ & $\begin{array}{l}260 \\
(42,0 \%)\end{array}$ & $4 / 0 / 17,4$ EUR & $20 / 20 / 34,5$ EUR \\
\hline $\begin{array}{l}\text { Spletni } \\
\text { slovar }\end{array}$ & $\begin{array}{l}83,4 \%) \\
(13,4 \%)\end{array}$ & $\begin{array}{l}310 \\
(50,1 \%)\end{array}$ & $0 / 0 / 16$ EUR & $20 / 50 / 36,7$ EUR \\
\hline $\begin{array}{l}\text { Mobilna } \\
\text { aplikacija }\end{array}$ & $\begin{array}{l}97 \\
(15,7 \%)\end{array}$ & $\begin{array}{l}344 \\
(55,6 \%)\end{array}$ & o / o / 6,9 EUR & $10 / 5 / 20,3$ EUR \\
\hline
\end{tabular}

Tabela 3: Koliko ste pripravljeni plačati za slovar?

Nazadnje so vprašani opredelili, ali so v spletnih slovarjih pripravljeni sprejeti oglase. 67,2 \% vprašanih se z oglaševanjem ne strinja, 32,8 \% pa je oglase pripravljenih sprejeti (Slika 17).

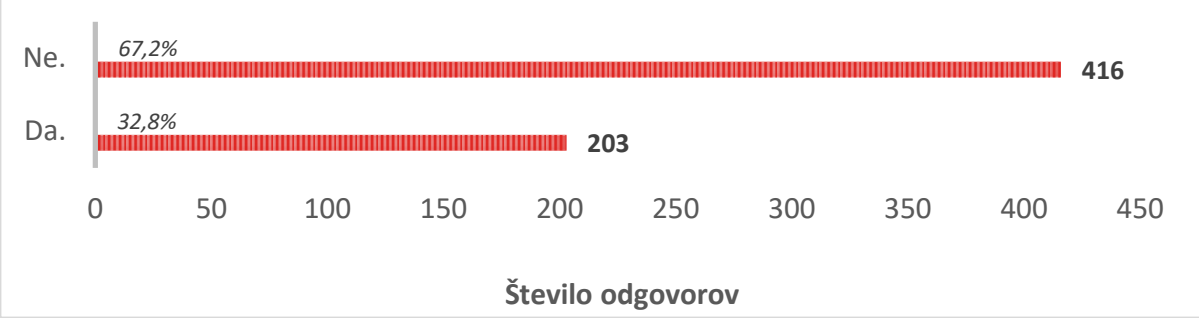

Slika 17: Ste v spletnih enojezičnih slovarjih pripravljeni sprejeti oglase? 


\subsection{Preferenčni format slovarja}

Anketa je spraševala tako po tipičnem načinu dostopa do enojezičnih slovarjev (možnih je bilo več odgovorov) kot tudi po preferenčni obliki dostopa (izbrati je bilo treba en sam odgovor). Slika 18 prikazuje število izbir za posamezno vrsto dostopa. Velika večina vprašanih je označila, da dostopajo do slovarja z računalnikom (91,1\%), sledita uporaba knjižne oblike (42,2 \%) in telefona (34,9 $\%)$, najmanj pa so za dostop do slovarjev v uporabi tablice (13,7 \%).

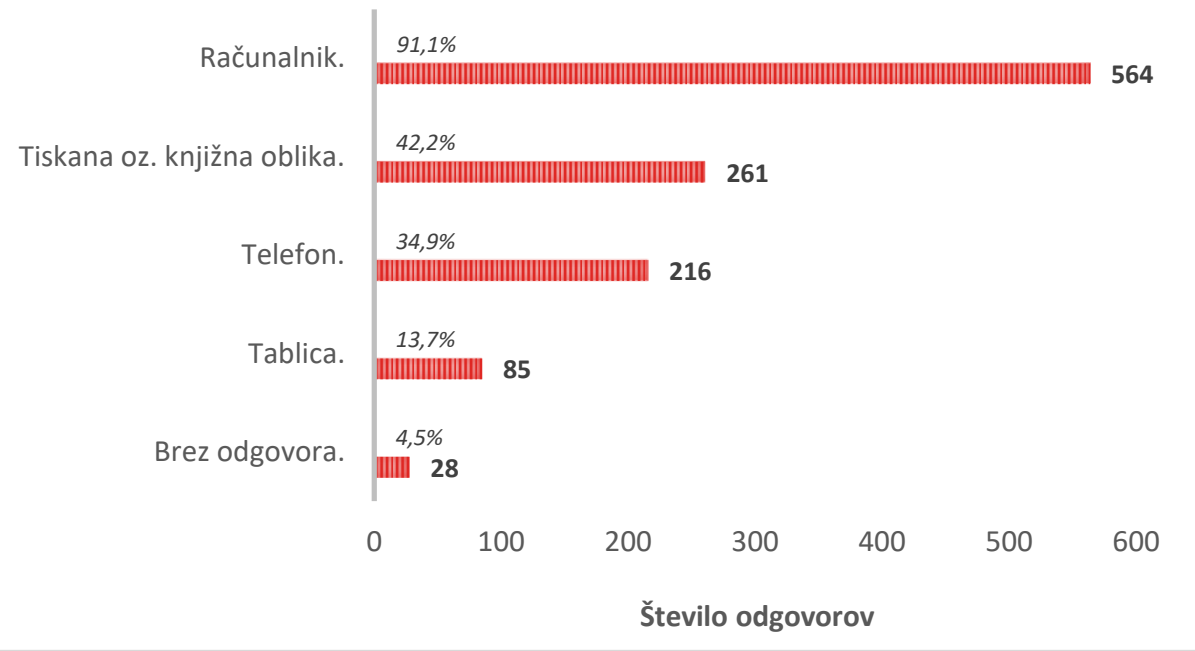

Slika 18: Kako dostopate do enojezičnih slovarjev, ki jih uporabljate?

K strnjenim podatkom Slike 18 je mogoče dodati tudi podatke o kombiniranih dostopih. Na zgolj en način do slovarja dostopa 217 vprašanih (35,1 \%), od tega 192 na računalniku, 19 do tiskanih slovarjev in 6 prek telefona. Na dva načina dostopa do slovarja 240 vprašanih (38,8 \%), od tega 136 v kombinaciji računalnik-tisk, 90 računalnik-telefon, 12 računalnik-tablica in 2 tisk-telefon. $\mathrm{Na}$ tri načine dostopa do slovarja 107 vprašanih (17,3\%), od tega $61 \mathrm{v}$ kombinaciji računalnik-telefon-tisk, 30 računalnik-tablica-telefon in 16 računalnik-tablica-tisk. Na vse naštete načine dostopa do slovarja 27 (4,4 \%) vprašanih. 
Kot je razvidno s Slike 19, je večini vprašanih računalniška slovarska oblika tudi najljubša (73,7 \%), ostale možnosti pa kot preferenčne nastopajo precej redkeje: tiskano obliko preferira $13,2 \%$, dostop prek telefona $5,7 \%$ in tablico $2,7 \%$ vprašanih.

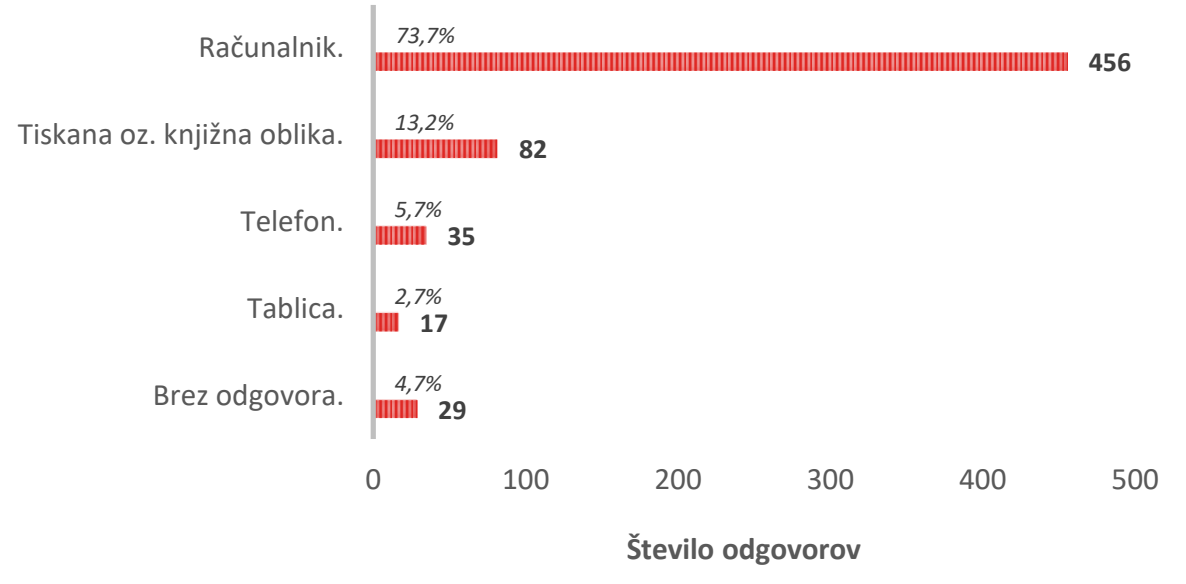

Slika 19: Katera oblika vam je za enojezične slovarje najljubša?

\subsection{Preferenčne značilnosti slovarja}

V zadnjem vprašanju ankete je bilo naštetih 11 značilnosti slovarja. Vprašani so jih razvrstili glede na svoje preference od najbolj do najmanj pomembnih, in sicer tako, da so naštete značilnosti z metodo povleci in spusti prenesli in razvrstili v drugi razdelek ekrana. Tabela 4 prikazuje rezultate s podatki o srednjih vrednostih ranga ter pogostosti razvrstitve posamezne značilnosti na prvo mesto, med prve tri (najpomembnejše) ter med zadnje tri (najmanj pomembne).

\begin{tabular}{|l|r|r|r|r}
\hline & $\begin{array}{r}\text { Mediana/modus } \\
\text { /aritm. sredina } \\
\text { ranga }\end{array}$ & $\begin{array}{r}\text { rang } \\
\text { Lastnost slovarja }\end{array}$ & $\begin{array}{r}\text { rang } \\
\mathbf{1 - 3}\end{array}$ & $\begin{array}{r}\text { rang } \\
\mathbf{9 - 1 1}\end{array}$ \\
\hline Zanesljiva vsebina. & $2 / 1 / 3$ & 254 & 465 & 15 \\
\hline
\end{tabular}




\begin{tabular}{|c|c|c|c|c|}
\hline $\begin{array}{l}\text { Prosta dostopnost } \\
\text { (brezplačnost). }\end{array}$ & $4 / 1 / 4$ & 125 & 295 & 56 \\
\hline Enostavnost uporabe. & $4 / 3 / 4$ & 79 & 290 & 37 \\
\hline $\begin{array}{l}\text { Sodobna vsebina (slovarska } \\
\text { gesla so pogosto posodobljena). }\end{array}$ & $4 / 2 / 4$ & 60 & 285 & 31 \\
\hline $\begin{array}{l}\text { Osnovanost na korpusnih } \\
\text { podatkih (slovar je v celoti } \\
\text { osnovan na realni jezikovni } \\
\text { rabi). }\end{array}$ & $6 / 7 / 6$ & 34 & 128 & 100 \\
\hline $\begin{array}{l}\text { Napredne možnosti za iskanje } \\
\text { po podatkih. }\end{array}$ & $5 / 5 / 5$ & 21 & 143 & 48 \\
\hline $\begin{array}{l}\text { Povezave na korpus (dostop do } \\
\text { primerov realne jezikovne rabe). }\end{array}$ & $6 / 5 / 6$ & 12 & 111 & 69 \\
\hline $\begin{array}{l}\text { Prilagodljivost (da se slovar } \\
\text { lahko spremeni glede na moje } \\
\text { potrebe). }\end{array}$ & $8 / 8 / 8$ & 6 & 32 & 250 \\
\hline $\begin{array}{l}\text { Multimedijske vsebine (zvočno } \\
\text { in slikovno gradivo ipd.) }\end{array}$ & $9 / 10 / 9$ & 3 & 18 & 384 \\
\hline $\begin{array}{l}\text { Spremljevalne vsebine } \\
\text { (jezikovne igre, kvizi, zapisi, } \\
\text { nasveti glede jezikovne rabe } \\
\text { itd.). }\end{array}$ & $10 / 11 / 9$ & 2 & 15 & 405 \\
\hline $\begin{array}{l}\text { Da lahko uporabniki slovarja } \\
\text { prispevamo svoje predloge za } \\
\text { dodajanje / popravljanje vsebin. }\end{array}$ & $9 / 11 / 9$ & 1 & 9 & 396 \\
\hline
\end{tabular}

Tabela 4: Katera lastnost enojezičnega slovarja za slovenščino se vam zdi pomembna? 
Na vprašanje je odgovorilo 597 vprašanih. Med njimi je kot najpomembnejšo značilnost slovarja večina izbrala zanesljivo vsebino (42,5 \%), ki prepričljivo vodi tudi v seštevku pojavnosti na prvih treh mestih (77,9 \%) ter se obenem najredkeje pojavlja na zadnjih treh mestih (2,5 \%). Sledijo prosta dostopnost (prva pri 20,9\%), enostavnost uporabe (prva pri 13,2 \%) in sodobna vsebina (prva pri 10,1 \%), ki se v seštevku na prvih treh mestih nahajajo pri 47,7 do 49,4 $\%$ sodelujočih. Prosta dostopnost se nekoliko pogosteje od preostalih dveh značilnosti ob tem pojavlja tudi med najmanj pomembnimi (pri 9,4 \%). Kot naslednja skupina značilnosti se ločujejo korpusna osnovanost (na prvih treh mestih pri $24 \%$ ), napredne možnosti iskanja (na prvih treh mestih pri 21,4 \%) in povezave na korpus (na prvih treh mestih pri 18,6 \%). Prilagodljivost (na prvih treh mestih pri 5,4 \%) je nekako na prehodu v skupino najmanj prioritetnih značilnosti, ki so: multimedijske vsebine (na prvih treh mestih pri $3 \%$ ), spremljevalne vsebine (na prvih treh mestih pri 2,5 \%) in uporabniška vključenost v slovarsko pripravo (na prvih treh mestih pri 1,5\%).

\section{IZSLEDKI IN DISKUSIJA}

\subsection{Izčrpen vir informacij za splošno javnost, ne popoln in ne za v smeti}

Glede na rezultate sta mnenju vprašanih najbližji trditvi, da splošni enojezični slovar slovenskega jezika predstavlja izčrpen vir informacij o slovenščini $(72,7$ \%) oz. izdelek, ki je uporaben za splošno javnost (69,3 \%). Trditve, ki so vezane na simbolično vlogo slovarja (da gre za vir posebnega pomena, avtoriteto, nacionalni simbol), je izbiralo manj, približno tretjina vprašanih. Kot je bilo že večkrat omenjeno, je treba upoštevati, da razumevanje kategorije »enojezičnega slovarja « med vprašanimi ni enovito, v razdelku 4.3 pa je opozorjeno na dvoumnost vprašanja, v katerem sodelujoči ne podajajo svojega osebnega pogleda, ampak ocenjujejo status slovarja oz. slovarjev v skupnosti. Ker rezultati na drugem mestu kažejo, da so vprašani izrazito nenaklonjeni oddati podedovani (tiskani) slovar: ga bodisi podariti knjižnici (9,4 \%), prodati $(3,1 \%)$ ali zavreči (o,8 \%), bi bilo mogoče sklepati, da tak odnos implicitno 
potrjuje simbolično vlogo slovarja. Vendar je nenaklonjenost mogoče razumeti tudi širše - zaradi posebnega odnosa do knjige kot take ali sentimentalne vrednosti, ker gre za zapuščino sorodnika. V nadaljnjih raziskavah bi bilo torej odnos do slovarja smiselno ocenjevati neposrednje $\mathrm{v}$ povezavi $\mathrm{z}$ medijem (preverjati, kakšen je odnos do simbolične vrednosti slovarja v tiskani obliki v primerjavi z enakim slovarjem $\mathrm{v}$ digitalni obliki, pri tem pa upoštevati tudi hibridnosti oblik in dostopov, ki jih digitalna situacija omogoča). Med rezultati opravljene ankete je vseeno mogoče izpostaviti zanimivo neskladje med izpričano preferenčnostjo digitalnega slovarskega formata (gl. 4.4) in dejstvom, da kar polovica vprašanih $(51,1 \%)$ odgovarja, da bi obdržali podedovani tiskani slovar zato, da ga bodo uporabljali (in ne iz drugih razlogov, ki so tudi na voljo med odgovori). Ob tem je zgovorno, da imajo vprašani do dejanske slovarske rabe, ki je po večini računalniška, precej pragmatičen odnos: če v slovarju besede ne najdejo, se obrnejo na splet (79,8 \%), v druge (sodobnejše) jezikovne vire (59,3 \%) ali vprašajo za mnenje druge ljudi (44,3 \%). Iz visokega deleža odgovorov $\mathrm{v}$ teh kategorijah lahko sklepamo o razumevanju slovarja kot jezikovnega vira, ki je morda privzeta, ne pa nujno edina (prava) možnost za reševanje jezikovnih vprašanj - ali če sledimo opredelitvam iz Stabej (2015: 21), slovar je razumljen referenčno, ne pa absolutno merodajno. Vprašanih, ki neobstoj besede v slovarju interpretirajo v smislu, da »očitno ne gre za pravo besedo«, je kljub temu kar $11 \%$; potreba po izobraževanju in osveščanju o namenu in omejitvah slovarja kot jezikovnega vira torej o(b)staja.

5.2 Raba slovarja za preverbo slišanega/prebranega in pripravo pisnih nalog

Enojezični slovar slovenskega jezika vprašanim predstavlja predvsem vodilo pri reševanju jezikovnih dilem in odločanju med jezikovnimi izbirami: največ vprašanih je izbralo rabo za preverbo slišanih ali prebranih besed (74,5 \%), kar ne preseneča, saj je odgovor širok in $\mathrm{v}$ določeni meri prekriven $\mathrm{z}$ drugimi odgovori (kar je problematično); za razreševanje nestrinjanj glede jezikovne rabe uporablja slovar $67 \%$ vprašanih in za jezikovno korekcijo besedil 57,5 \%. $\mathrm{Na}$ drugem mestu ( $\mathrm{v}$ seštevku kategorij) je raba slovarja za jezikovno 
produkcijo, predvsem za tvorbo besedil v službenem in študijskem okolju (73 \%), bistveno manj za pisanje besedil, kot je življenjepis (44,7 \%), za kreativno pisanje (26 \%) ter pisanje računalniško posredovanih sporočil (25\%). Preostali odgovori pokrivajo rabo za namene recepcije: za branje knjig, časopisov itd. rabi slovar 30,5 \% vprašanih, za branje uradnih dokumentov $28,9 \%$. Ugotovitve so skladne z izsledki analize uporabniških slovarskih potreb, ki kažejo, da jezikovni uporabniki tipično potrebujejo primerjavo dveh ali več jezikovnih možnosti, jasno opredelitev razlik med razpoložljivimi variantami in ločitev (za dani kontekst) ustreznejših jezikovnih izbir od manj ustreznih (Arhar Holdt idr. 2015: 209-210). Pri povzemanju rezultatov ankete pa je (poleg že navedenih zadržkov) seveda treba upoštevati, da odgovori odslikavajo le razpoložljive, vprašanim poznane možnosti ter njihove tipične življenjske situacije. Da se npr. slovar redko uporablja za branje uradnih besedil ne pomeni nujno, da vprašani za dekodiranje tovrstnih besedil slovarja ne potrebujejo, morda uradna besedila berejo redko ( $\mathrm{v}$ primerjavi $\mathrm{z}$ drugimi situacijami rabe, do katerih so se opredeljevali), morda razpoložljivi slovarji problematičnega besedišča ne pokrivajo adekvatno, morda problem jezika uradnih besedil presega domet slovarja, ker težave posegajo na raven skladnje, ali kaj četrtega. V nadaljnjih anketiranjih bi bilo vprašanje glede rabe treba natančneje ubesediti in dodatno razdelati ter ponuditi vprašanim možnost, da odgovore opremijo s pojasnili.

\subsection{Izrazita podpora javnemu financiranju}

Vprašani so izrazito naklonjeni javnemu financiranju izdelave splošnih enojezičnih slovarjev (kakorkoli že široko si to kategorijo predstavljajo): kar 96,1 \% jih je mnenja, da je javno financiranje utemeljeno. Argumenti za brezplačnost pričajo o dokaj uravnoteženem sobivanju simbolne in uporabne vloge slovarja, kot ju opredeljuje Stabej (2009: 118-119): ohranjanje kulturne dediščine je ključni agument za podporo pri približno polovici vprašanih (49,9 \%), za 37,8 \% pa je ključni argument uporabnost slovarja za javnost. Zanimive so razlike $\mathrm{v}$ pripravljenosti plačevanja za slovarje $\mathrm{v}$ različnih oblikah: pri digitalnih slovarjih (namizna, spletna, mobilna oblika) brezplačnost pričakuje 
cca. polovica vprašanih (med 42,o in 55,6 \%), medtem ko je za tiskani slovar ta številka pol nižja (25,7 \%). Tudi vprašani, ki so za slovar pripravljeni plačati, vrednotijo tiskane različice znatno više: če bi za namizni slovar odšteli povprečno 34,5 EUR, bi za tiskanega 61,7 EUR. Zdi se, da stroški tiskane slovarske naklade $\mathrm{v}$ očeh vprašanih upravičujejo plačljivost slovarja bolj kot stroški vzdrževanja digitalnega slovarja (vmesnik, mobilna aplikacija, vzdrževanje strežnika, tehnične posodobitve itd.), ki si jih splošna javnost gotovo težje konkretno predstavlja. Kljub nenavdušenosti za lastno plačevanje digitalnih slovarjev vprašani tudi na vključevanje oglasov ne gledajo z naklonjenostjo: dobri dve tretjini (67,2 \%) oglasov v spletni različici slovarjev ne bi sprejela. Rezultati torej mdr. nakazujejo potrebo po seznanjanju javnosti s procesi digitalnega slovaropisja in spremembami, ki jih slednje prinaša ne le na ravni oblike in vsebine, ampak tudi v samo pripravo slovarskih priročnikov.

\subsection{Primarnost računalniškega dostopa do slovarjev}

Računalniška oblika dostopa do slovarskih podatkov je med vprašanimi prepričljivo primarna, tako v vsakodnevni praksi (pri 91,1 \%) kot v smislu uporabniških preferenc (pri 73,7 \%). Ostale oblike dostopa se v rabi pojavljajo, vendar običajno $\mathrm{v}$ kombinaciji z dostopom do računalnika (kar je skladno $\mathrm{z}$ raziskavo Gorjanc (2014) na vzorcu 102 študentov medjezikovnega posredovanja, tolmačenja, prevajalstva in novinarstva). Vprašanih, ki uporabljajo izključno knjižno obliko, je le 3,1 \%, vendar je preferenčna za 13,2 \% (prim. 2 \% pri Gorjanc 2014). Podobno redko se pojavlja dostop do slovarja le s telefonom (1,0 \%), telefon kot preferenca pa se pojavlja pri 5,7 \% vprašanih. Tablice kot orodje za dostop do slovarjev v našem prostoru trenutno niso pogosto v rabi ne posebej priljubljene. Za slovenske splošne enojezične slovarje specializirane mobilne aplikacije še niso na voljo in pričakovati je, da se bo ob njihovem pojavu razmerje $\mathrm{v}$ rabi spremenilo. $\mathrm{V}$ vsakem primeru pa je predvidljivo, da bo digitalni slovar kot delovni pripomoček najpogosteje rabljen na napravah, ki se tudi sicer uporabljajo za delo. Prihajajočim spremembam navkljub trenutni rezultati povsem nedvoumno kažejo, da mora biti (tukaj in 
zdaj) glavnina pozornosti pri pripravi in izdaji slovarjev brez kakršnegakoli zadržka usmerjena v njegovo digitalno (in v prvem koraku računalniško) obliko, na kar je bilo v stroki že večkrat opozorjeno (v slovenskem prostoru npr. v Krek idr. 2013, Gorjanc idr. (ur.) 2015).

\subsection{Zanesljivost, brezplačnost, enostavnost uporabe in sodobna vsebina}

Med prioritetami slovarskih značilnosti prepričljivo vodi zanesljivost vsebine (na prvih treh mestih pri 77,9\%), sledijo prosta dostopnost (na prvih treh mestih pri 49,4\%), enostavnost uporabe (na prvih treh mestih pri 48,6 \%) in sodobna vsebina (na prvih treh mestih pri $47,7 \%$ ). S tem se tudi za slovenski prostor potrdijo ugotovitve, da je zanesljivost vsebine v očeh uporabnikov v lastni jakostni skupini oz. da jim pomeni konstanto, ne spremenljivke (Müller Spitzer 2014: 168), bi bilo pa v nadaljevanju zanimivo raziskati tudi, po katerih kriterijih uporabniki zanesljivost presojajo (ali jo sami, morda presojo prepuščajo stroki ali financerjem). V raziskavi Müller Spitzer so med pomembnimi značilnostmi spletnih slovarjev še jasnost, sodobnost vsebine, hitrost in dostopnost, torej primerljivo slovenskim rezultatom, pri čemer je višje prioretiziranje brezplačnega dostopa $\mathrm{v}$ slovenskem prostoru mogoče povezati z že omenjenim pričakovanjem javnega financiranja. Korpusna osnovanost, povezave na korpuse ter napredne iskalne možnosti so glede na prioritete vprašanih nekje na sredini (posebej pomembne za cca. četrtino vprašanih), nekoliko za njimi zaostaja prilagodljivost, prepričljivo na konec pa so umeščene multimedijske in spremljevalne vsebine ter možnost uporabniškega vključevanja. ${ }^{13}$ Rezultati ponujajo zanimivo sliko, ki jo je vredno primerjati s trenutno realnostjo (npr. glede proste dostopnosti, enostavnosti uporabe in sodobne vsebine obstoječih slovarskih virov), obenem pa jih je treba razumeti $v$ luči že izpostavljenega dejstva, da je seznanjenost vprašanih $s$

13 Uporabniško vključevanje kot prioriteta očitno ne konkurira ostalim slovarskim značilnostim, vendar je v slovenskem prostoru razumljeno pozitivno, kar razkriva slovenski dodatek k vprašalniku: samo 11,5 \% vprašanih uporabniškega sodelovanja ne podpira, kar 47,7 \% vprašanih pa navaja, da bi pri pripravi slovarja tudi osebno sodelovali. 
slovaropisnim procesom omejena, kot velja tudi za predstavljivost še nerealiziranih možnosti - značilnosti, ki so znane in v praksi preizkušene, se v tovrstnih raziskavah vedno uvrščajo više od potencialnih oz. napovedujočih se.

\section{SKLEP}

V prispevku smo predstavili rezultate slovenskega dela mednarodne raziskave o odnosu jezikovnih uporabnikov do splošnih enojezičnih slovarjev. Prve analize so izpostavile mesta, ki bi se jim bilo v nadaljevanju treba natančneje posvetiti, predvsem šibkosti obstoječega vprašalnika (nejasna vprašanja in vprašanja, ki bi jih bilo smiselno vsebinsko razširiti ali poglobiti) ter problem strukture vzorca, ki ga je mogoče v nadaljevanju še ciljno dopolnjevati in širiti. Kot je bilo omenjeno, nadaljevanje čakajo kvalitativne analize s statističnim testiranjem povezav med izbranimi odgovori, analiza slovensko specifičnega dela rezultatov in primerjalni mednarodni pogled, ki bo razkril, v čem smo glede odnosa do slovarjev v Sloveniji drugačni in v čem podobni ostali Evropi.

Da je odnos uporabnikov do splošnih enojezičnih slovarjev vznemirljiva in izredno kompleksna tema, za stroko ni posebna novost. Ločevanje na simbolno in uporabno funkcijo slovarja, na knjigoljubne in tabličarske uporabnike ponuja izhodišča, ki jih potrebujemo za konceptualne in diskusijske premisleke, $\mathrm{v}$ realnosti pa slovarske vloge, naloge in uporabniške prakse sobivajo na načine, ki s slovaropisnega stališča niso nujno predvidljivi niti povsem logični. Zato je toliko pomembneje, da obstoječe predpostavke preverjamo na osnovi metodološko utrezno pridobljenih empiričnih podatkov in da s pomočjo teh tudi začrtujemo nova raziskovalna vprašanja. Predstavljeni rezultati denimo nakazujejo, da bi bilo v prihodnje smotrno odmeriti čas seznanjanju javnosti z namenom in procesi digitalnega slovaropisja, ki je prav v slovenskem prostoru $\mathrm{v}$ prvih vrstah inovativosti in metodološkega razvoja stroke - tudi po zaslugi upoštevanja mnenj, predlogov in potreb slovarskih oz. širše jezikovnih uporabnikov. 


\section{ZAHVALA}

Delo sta podprla Center za jezikovne vire in tehnologije Univerze v Ljubljani in Center za uporabno jezikoslovje zavoda Trojina (infrastrukturni program ARRS Io-0051). Zahvaljujemo se vsem, ki so sodelovali v raziskavi in njeni diseminaciji. Zahvala gre tudi recenzentoma za natančno branje in konstruktivne predloge za izboljšavo prispevka.

\section{LITERATURA}

Arhar Holdt, Šs. (2015): Uporabniške raziskave za potrebe slovenskega slovaropisja: prvi koraki. V V. Gorjanc idr. (ur.): Slovar sodobne slovenščine: problemi in rešitve: 136-148. Ljubljana: Znanstvena založba Filozofske fakultete.

Arhar Holt, Š., Čibej, J. in Zwitter Vitez, A. (2015): S pomočjo uporabniških jezikovnih vprašanj in mnenj do boljšega slovarja. V V. Gorjanc idr. (ur.): Slovar sodobne slovenščine: problemi in rešitve: 196-214. Ljubljana: Znanstvena založba Filozofske fakultete.

Arhar Holdt, Š., Kosem, I. in Gantar, P. (2016): Dictionary user typology: the Slovenian case. V T. Margarlitadze in G. Meladze (ur.): Lexicography and linguistic diversity: proceedings of the XVII EURALEX International Congress: 179-187. Tbilisi: Ivane Javakhishvili Tbilisi State University. http://euralex2016.tsu.ge/publication2016.pdf.

Arhar Holt, Š., Čibej, J. in Zwitter Vitez, A. (2017): Value of language-related questions and comments in digital media for lexicographical user research. International Journal of Lexicography, 30 (3): 285-308. Doi: https://doi.org/10.1093/ijl/ecw017.

Bogaards, P. (2003): Uses and users od dictionaries. V P. van Sterkenburg (ur.): A practical Guide to Lexicography: 26-33. Amsterdam in Philadelphia: John Benjamins.

Čibej, J., Fišer, D. in Kosem, I. (2015): The role of crowdsourcing in lexicography. V I. Kosem idr. (ur.): Electronic lexicography in the 21st 
century: linking lexical data in the digital age: 70-83. Ljubljana: Trojina, Institute for Applied Slovene Studies; Brighton: Lexical Computing.

Gorjanc, V., Gantar, P., Kosem, I. in Krek, S., ur. (2015): Slovar sodobne slovenščine: problemi in rešitve. Ljubljana: Znanstvena založba Filozofske fakultete.

Gorjanc, V. (2017): Nije rečnik za seljaka. Beograd: Biblioteka XX vek.

Gorjanc, V. (2014): Slovar slovenskega jezika v digitalni dobi. V: I. Grahek Irena in S. Bergoč (ur.). Novi slovar za 21. stoletje: e-zbornik s Posveta o novem slovarju slovenskega jezika na Ministrstvu za kulturo, 12. februar 2014. Ljubljana: Ministrstvo za kulturo. 2014. http://www.mk.gov.si/fileadmin/mk.gov.si/pageuploads/Ministrstvo/s lovenski_jezik/E_zbornik/1-_Vojko_Gorjanc__Slovar_MK_tekst_FINAL.pdf.

Kosem, I. (2017). The European survey of dictionary use. V: Electronic lexicography in the 21st century: lexicography from scratch: 53. Leiden: Dutch Language Institut; Brno: Lexical Computing; Ljubljana: Trojina Institute for Applied Slovene Studies.

Kosem, I., Gantar, P. in Krek, S. (2013): Automation of lexicographic work: an opportunity for both lexicographers and crowd-sourcing. V I. Kosem idr. (ur.): Electronic lexicography in the 21st century: thinking outside the paper: 32-48. Ljubljana: Trojina, Institute for Applied Slovene Studies; Tallinn: Eesti Keele Instituut.

Krek, S., Kosem, I. in Gantar, P. (2013): Predlog za izdelavo Slovarja sodobnega slovenskega jezika. Izd. 1.1. Ljubljana: s. n. http://www.sssj.si/datoteke/Predlog_SSSJ_v1.1.pdf.

Logar, N. (2009): Slovenski splošni in terminološki slovarji: za koga? V M. Stabej (ur.): Infrastruktura slovenščine in slovenistike. Obdobja 28: 
225-231. Ljubljana: Znanstvena založba Filozofske fakultete.

Logar, N., Gantar, P., Arhar Holdt, Š., Gorjanc, V., Kosem, I., Krek, S. in Stabej, M. (2017): Odziv na "Anketo o slovenščini” projekta Jezikovna politika Republike Slovenije in potrebe uporabnikov. Slovenščina 2.o, 5 (1): $27-37$.

Müller-Spitzer, C., ur. (2014): Using Online Dictionaries. Berlin, Boston: De Gruyter Mouton.

Rozman, T. (2014): Upoštevanje ciljnih uporabnikov pri izdelavi enojezičnega slovarja za tujce. Jezik in slovstvo, 49 (3/4): 63-75.

Stabej, M. (2009): Slovarji in govorci: kot pes in mačka? Jezik in slovstvo, 54 (3/4): $115-138$.

Stabej, M. (2015): Daj mi slovar in spremenim ti (jezikovno) skupnost. V V. Gorjanc idr. (ur.): Slovar sodobne slovenščine: problemi in rešitve: 1631. Ljubljana: Znanstvena založba Filozofske fakultete.

Tarp, S. (2009): Reflections on Lexicographical User Research. Lexikos 19 (1): 275-296.

Welker, H. A. (2013a): Methods in Research of Dictionary Use. V R. Gouws idr. (ur): Dictionaries. An International Encyclopedia of Lexicography: Supplementary Volume: Recent Developments with Focus on Electronic and Computational Lexicography: 540-547. Berlin, New York: Walter de Gruyter.

Welker, H. A. (2013b). Empirical Research into Dictionary Use since 1990. V R. Gouws idr. (ur): Dictionaries. An International Encyclopedia of Lexicography: Supplementary Volume: Recent Developments with Focus on Electronic and Computational Lexicography: 531-540. Berlin, New York: Walter de Gruyter. 


\section{THE ATTITUDE OF LANGUAGE USERS \\ TOWARDS GENERAL MONOLINGUAL \\ DICTIONARIES: THE SLOVENE PERSPECTIVE}

The paper presents an international survey on the attitude of language users towards general monolingual dictionaries (GMDs), focusing on the data collected among Slovene participants. The survey was designed within the European Network for e-Lexicography (ENeL) in 2017. The study aims to provide answers to the following research questions: what is the attitude of users towards GMDs as reference books; which language problems do GMDs typically help resolve; and which features of GMDs do users perceive as most important. A questionnaire addressing these topics was translated to the languages of 29 participating European countries and disseminated on national levels. In total, 9,562 questionnaires were collected. In Slovenia, 619 individuals (including both regular as well as non-regular dictionary users) participated in the survey. The results confirmed the pre-existing presumption that in Slovenia (as elsewhere), users typically access dictionaries using a computer. Computer access is also highly preferred compared to both the printed format as well as smartphones and tablets. Secondly, participants often use GMDs to check the appropriateness of language choices (either their own or those made by other language users). GMDs are, however, not perceived as the only and absolute reference when it comes to solving language dilemmas: in case of information gaps, the majority of users turn to alternative options such as Internet browsers. Furthermore, GMDs are typically seen as an exhaustive source of information about Slovene intended for the general public. While the symbolic role of the dictionary (as an authority or a national symbol) is reflected less often in the responses, it is implicitly indicated by the participants' reluctance to relinquish printed dictionaries in spite of the fact that they only use the digital versions. Finally, the participants strongly support public financing of GMD projects. Accordingly, free availability is placed among the top-priority features of GMDs, preceded only by the reliability of their content. The top priorities also include ease of use and up-todate content. In the paper, the detailed presentation of the results is complemented by a discussion on the possible future improvements of the 
questionnaire. The findings can be used to improve Slovene dictionary resources and to plan further steps of lexicographic user research.

Keywords: user research, dictionary use, attitude towards dictionaries, general monolingual dictionaries

To delo je ponujeno pod licenco Creative Commons: Priznanje avtorstvaDeljenje pod enakimi pogoji 4.o Mednarodna.

This work is licensed under the Creative Commons Attribution-ShareAlike 4.0 International.

https://creativecommons.org/licenses/by-sa/4.o/

(c) $\underset{\mathrm{ar}}{(1)(2)}$ 